\title{
Strategic Petroleum Reserve Annual Report for Calendar Year 1998
}

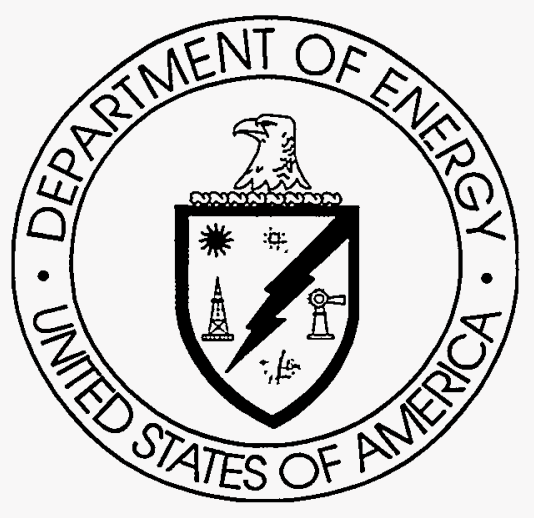

U.S. Department of Energy

Assistant Secretary for Fossil Energy

Office of Strategic Petroleum Reserve

Washington, D.C. 20585

http://www.fe.doe.gov/spr/spr.html

http://www.spr.doe.gov

MASTER

DISTRIBUTION OF THS DOCUMENT IS UALHUTED 


\section{DISCLAIMER}

Portions of this document may be illegible in electronic image products. Images are produced from the best available original document. 


\section{TABLE OF CONTENTS}

EXECUTIVE SUMMARY $\ldots \ldots \ldots \ldots \ldots \ldots \ldots \ldots \ldots \ldots \ldots \ldots \ldots \ldots \ldots \ldots \ldots \ldots$

Statement of U.S. Policy on the Strategic Petroleum Reserve $\ldots \ldots \ldots \ldots \ldots \ldots \ldots \ldots 1$

Legislation.$\ldots \ldots \ldots \ldots \ldots \ldots \ldots \ldots \ldots \ldots \ldots \ldots \ldots \ldots \ldots \ldots \ldots \ldots$

Facilities Life Extensions . . . . . . . . . . . . . . . . . . . . . . . . . . . 1

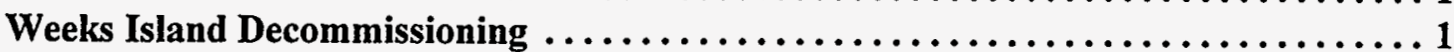

Crude Oil Inventory $\ldots \ldots \ldots \ldots \ldots \ldots \ldots \ldots \ldots \ldots \ldots \ldots \ldots \ldots \ldots \ldots \ldots$

Commercialization of Distribution Facilities $\ldots \ldots \ldots \ldots \ldots \ldots \ldots \ldots \ldots \ldots \ldots 1$

Foreign Trade Zone Designation for Big Hill $\ldots \ldots \ldots \ldots \ldots \ldots \ldots \ldots \ldots \ldots \ldots \ldots$

Regional Petroleum Reserve Report $\ldots \ldots \ldots \ldots \ldots \ldots \ldots \ldots \ldots \ldots \ldots \ldots \ldots \ldots$

PROGRAM MISSION $\ldots \ldots \ldots \ldots \ldots \ldots \ldots \ldots \ldots \ldots \ldots \ldots \ldots \ldots \ldots \ldots \ldots \ldots \ldots \ldots \ldots \ldots$

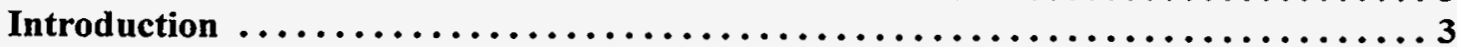

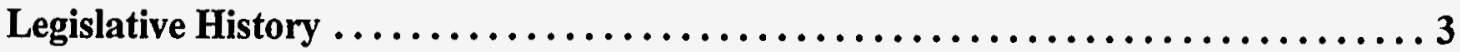

Strategic Petroleum Reserve Plan and Amendments $\ldots \ldots \ldots \ldots \ldots \ldots \ldots \ldots \ldots 5$

Statement of Policy on the Strategic Petroleum Reserve ................. 6

PROGRAM MANAGEMENT $\ldots \ldots \ldots \ldots \ldots \ldots \ldots \ldots \ldots \ldots \ldots \ldots \ldots \ldots \ldots \ldots$

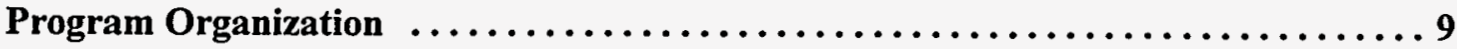

Program Contract Support $\ldots \ldots \ldots \ldots \ldots \ldots \ldots \ldots \ldots \ldots \ldots \ldots \ldots \ldots \ldots \ldots, \ldots \ldots \ldots$

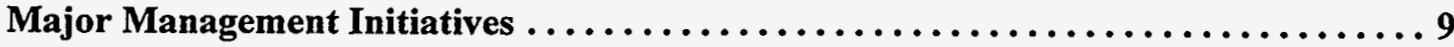

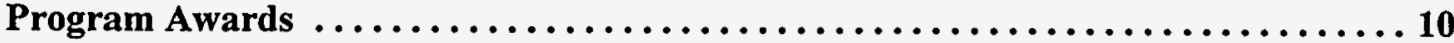

STORAGE PROGRAM $\ldots \ldots \ldots \ldots \ldots \ldots \ldots \ldots \ldots \ldots \ldots \ldots \ldots \ldots \ldots \ldots \ldots \ldots \ldots \ldots \ldots$

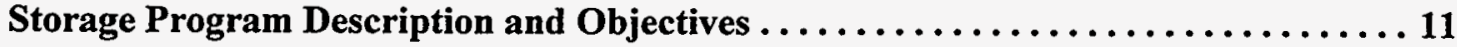

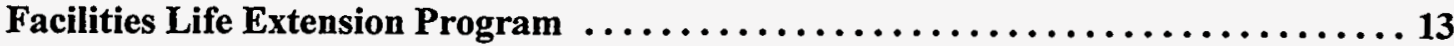

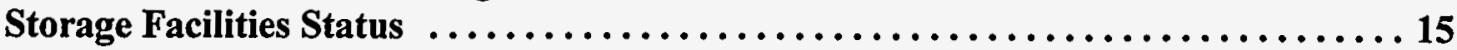

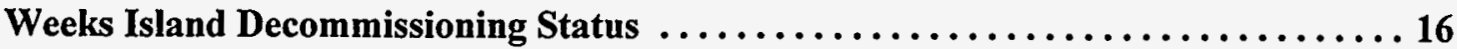

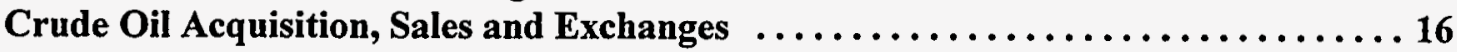

Crude Oil Inventory Status . . . . . . . . . . . . . . . . . . . . . . . . 17

EMERGENCY RESPONSE CAPABILITIES $\ldots \ldots \ldots \ldots \ldots \ldots \ldots \ldots \ldots \ldots \ldots \ldots \ldots . \ldots \ldots$

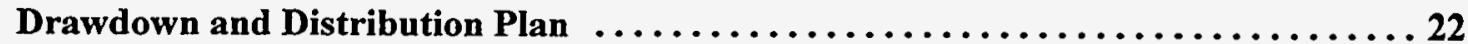

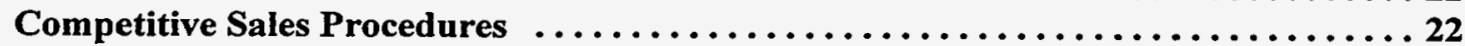

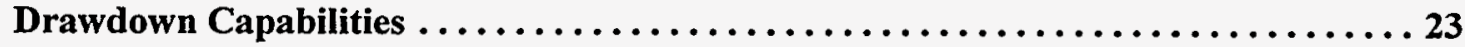

Drawdown Readiness Activities ............................... 26

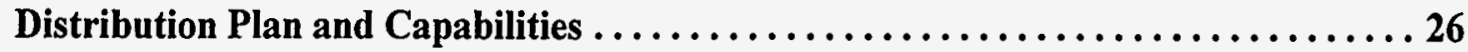

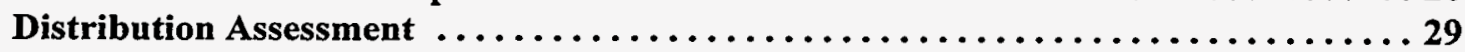

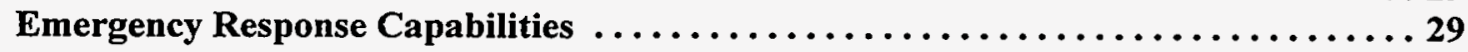

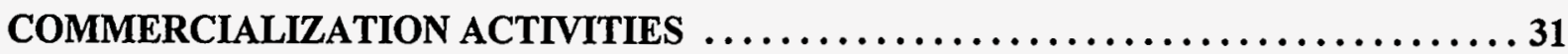

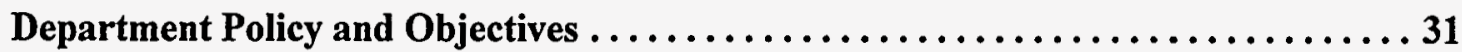

Commercial Leases of Distribution Facilities ........................ 31

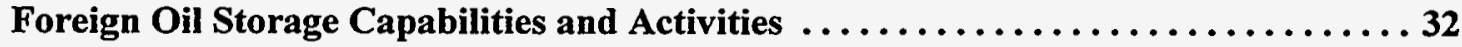

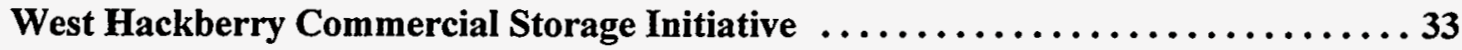


FOREIGN TRADE ZONE DESIGNATION FOR BIG HILL

On September 22, 1998, the Big Hill site was activated as a foreign trade zone subzone. This status enables potential customers to store oil at the site without having to pay customs fees and certain taxes.

\section{REGIONAL PETROLEUM RESERVE REPORT}

In June 1998, the Department submitted a report to the Congress on the costs/benefits of establishing a heating oil component to the Strategic Petroleum Reserve for the Northeast, in response to concerns from consumers and members of Congress about high prices for heating oil and historically low levels of inventories.

The report did not contain any conclusions, but the analysis formed the basis for the Department's conclusion in the Statement of Policy that a crude oil reserve, located in the Gulf Coast region. is the most cost-effective way to protect the Nation during a severe oil supply interruption. 
Strategic Petroleum Reserve Annual Report 1998

\section{PROGRAM MISSION}

\section{INTRODUCTION}

The Strategic Petroleum Reserve was established in 1975 as an emergency response to the 1973 Arab oil embargo. It is authorized by the Energy Policy and Conservation Act (EPCA), and by the comprehensive energy plans of all Administrations since 1975, in recognition of the long-term dependence of the United States on imported crude oil and petroleum products. Section 165 of EPCA requires the Secretary of Energy to submit an Annual Report to the President and the Congress.

On May 13, 1998, the Department published a Statement of Administration Policy which reaffirmed its commitment to maintain a Government-owned and controlled, centrally located Strategic Petroleum Reserve of crude oil. The Reserve is to be used solely for responding to the types of severe oil supply interruptions presently contemplated in EPCA.

Over the past twenty years, the Reserve has grown as large as 592 million barrels - a peak reached in 1994. From 1994 to 1996, nearly 28 million barrels were sold to raise revenues for the U.S Treasury. As of December 31, 1998, the crude oil inventory was $561,108,127$ barrels which equated to 60 days of net oil imports during 1998. The United States now relies on a combination of both the Reserve and private stocks to meet its oil storage obligations to the International Energy Agency.

\section{LEGISLATIVE HISTORY}

The Strategic Petroleum Reserve was authorized on December 22, 1975, when Congress enacted the EPCA (Public Law 94-163), to reduce the impact of a severe energy supply interruption, and to carry out the obligations of the United States under the International Energy Program.

EPCA was amended by Title VIII of the Energy Security Act (Public Law 96-294), enacted on June 30, 1980. This Act established a minimum average daily fill rate of 100,000 barrels and precluded the sale of Naval Petroleum Reserve Numbered 1 (Elk Hills, California) crude oil except to fill the Strategic Petroleum Reserve, unless the Reserve was being filled at the minimum rate or had an inventory of 500 million barrels.

The Energy Policy and Conservation Amendments Act of 1985 (Public Law 99-58), enacted on July 2, 1985, extended the provisions of Title I, Part B, of the EPCA relating to the Strategic Petroleum Reserve until June 30, 1989, and directed the Secretary of Energy to conduct a sale or exchange of 1.1 million barrels of crude oil to test the drawdown and distribution capabilities of the Strategic Petroleum Reserve.

The Omnibus Budget Reconciliation Act of 1986 (Public Law 99-509), enacted on October 21, 1986, amended EPCA to require that the Strategic Petroleum Reserve be filled to 750 million barrels, and increased the minimum rate under the Naval Petroleum Reserve limitation to 75,000 barrels a day. 
Strategic Petroleum Reserve Annual Report 1998

Public Law 101-46, an Act to extend Title I of EPCA, enacted on June 30, 1989, extended Strategic Petroleum Reserve authorities contained in EPCA until April 1, 1990. The Act also required the Secretary to submit a report to Congress by February 1, 1990, on alternative means of financing oil acquisition for the Strategic Petroleum Reserve. Short term extensions of the Strategic Petroleum Reserve authorities contained in EPCA were enacted on March 31, 1990 (Public Law 101-262), and August 10, 1990 (Public Law 101-360).

On September 15, 1990, the President signed the Energy Policy and Conservation Act Amendments of 1990 (Public Law 101-383) extending authorities until September 30, 1994. This legislation also contained provisions to amend drawdown authorities, require a Strategic Petroleum Reserve Plan Amendment for completion of storage capacity for one billion barrels, authorize drawdown and distribution tests. and provide for a refined petroleum product reserve test program.

On October 24, 1992, the President signed the Energy Policy Act of 1992 (Public Law 102-486) The bill included provisions to (1) add new conditions for drawdown in emergency situations involving a supply reduction of significant scope and duration, coupled with a severe price increase likely to cause a major adverse impact on the nation's economy. (2) enlarge the Reserve to one billion barrels. (3) permit the Secretary to make payment in advance for delivery of petroleum product either owned or not owned by the United States for storage in the Strategic Petroleum Reserve or non-Strategic Petroleum Reserve facilities. (4) give the President discretionary authority to acquire domestic stripper well oil at competitive prices to fill the Reserve, and (5) amend the eligibility criteria for a Regional Petroleum Reserve.
On October 22, 1994, the President signed into law the Energy Policy and Conservation Act Amendments Act of 1994 (Public Law 103-406) which extended authorities to June 30, 1996.

The Balanced Budget Downpayment Act (Public Law 104-99) was enacted on January 26,1996 , and required the sale of up to $\$ 1.00$ million of Weeks Island oil to fund decommissioning activities.

The Omnibus Consolidated Rescissions and Appropriations Act of 1996 (Public Law 104-134) was enacted on April 26, 1996, and required the sale of $\$ 227$ million of Weeks Island oil for deficit reduction.

The Omnibus Consolidated Appropriations Act (Public Law 104-208) was enacted on September 30, 1996, and appropriated $\$ 220$ million for the Strategic Petroleum Reserve in fiscal year 1997 to be financed through the sale of Reserve oil.

The Strategic Petroleum Reserve authorities expired on June 30, 1996. On October 14, 1996, Public Law 104-306 extended the Strategic Petroleum Reserve authorities until September 30, 1997. After the expiration of Strategic Petroleum Reserve authorities on September 30,1997, these authorities were not reauthorized until June 1998.

The Balanced Budget Act of 1997 (Public Law 105-33), enacted August 5, 1997, added a new section 168 to EPCA, authorizing the leasing of underutilized Strategic Petroleum Reserve facilities for the storage of oil owned by a foreign government or its representatives.

The Department of the Interior and Related Agencies Appropriations, 1998 (Public Law 105-83) was enacted on November 14, 1997, and appropriated $\$ 207.5$ million for the Strategic 
Petroleum Reserve in fiscal year 1998 to be financed through the sale of Reserve oil.

The 1998 Supplemental Appropriations and Rescissions Act (Public Law 105-174) was enacted on May 1, 1998 and included a provision which prohibited the sale of Strategic Petroleum Reserve oil, contingent upon a Presidential determination that a sale would "be imprudent in light of current market conditions" and a designation of the $\$ 207.5$ million in foregone revenue as an emergency requirement under the Balanced Budget Act of 1985. The President made the requisite determination and declaration on May 8, 1998.

On June 1, 1998, the President signed Public Law 105-177 to extend certain EPCA programs. The Act extended authorities for the Strategic Petroleum Reserve and participation in the International Energy Program through September 30,1999 , and expanded the antitrust protection for U.S. companies participating in International Energy Agency activities. The Act also authorized the drawdown and distribution of the Strategic Petroleum Reserve only for the purposes described in the Act and required that the Secretary of Energy request funds for acquisition, transportation and injection of petroleum products for storage in the Reserve or provide a written explanation if no request for funds is made

The Omnibus Consolidated and Emergency Supplemental Appropriations Act. 1999(Public Law 105-277) was enacted on October 21. 1998. and includes $\$ 160.1$ million for the Strategic Petroleum Reserve.

On November 13, 1998, the President signed Public Law 105-388, an Act to extend energy' conservation programs under the Energy Policy and Conservation Act and the Energy Conservation and Production Act, and for other purposes The Act provides that, during a drawdown of the
Strategic Petroleum Reserve, the State of Hawaii may submit a binding offer for Strategic Petroleum Reserve oil and be entitled to purchase the oil at a price equal to the weighted average price of the successful competitive bids for oil in the category. Additionally, tankers destined for Hawaii would receive priority scheduling during a Strategic Petroleum Reserve drawdown.

\section{STRATEGICPETROLEUMRESERVE PLANAND AMENDMENTS}

The Energy Policy and Conservation Act, section 154 , required the preparation of a Strategic Petroleum Reserve Plan to address the development and implementation of the Strategic Petroleum Reserve. A Plan was submitted to the Congress on February 16, 1977, and became effective on April 18, 1977. The Plan has been amended five times, the last on February 11, 1999.

Strategic Petroleum Reserve Plan, Amendment No. 1 , accelerated the planned schedule for filling the Reserve. Amendment No. 2 to the Strategic Petroleum Reserve Plan authorized an increase in the Strategic Petroleum Reserve size from 500 million barrels to one billion barrels. The Amendment described Department of Energy plans to store 750 million barrels of petroleum in underground storage facilities.

On October 31, 1979, the Department of Energy submitted Amendment No. 3, a Distribution Plan for the Strategic Petroleum Reserve, to the Congress. The Distribution Plan described the methods for drawdown and distribution of petroleum from the five existing Strategic Petroleum Reserve storage sites.

On December 1, 1982, the President transmitted Amendment No. 4, a new Drawdown Plan, to the Congress for the use of the Strategic Petroleum Reserve. This Plan, required under the Energy 
Strategic Petroleum Reserve Annual Report 1998

Emergency Preparedness Act of 1982, went into effect immediately and provides procedures for the drawdown, sale, and distribution of petroleum from the Strategic Petroleum Reserve. The Drawdown Plan replaces the Distribution Plan established by Amendment 3.

Finally, Amendment No. 5 provides specifically for the Strategic Petroleum Reserve to acquire "crude oil which the United States is entitled to receive inkind as royalties from production on Federal lands" under subsection 160(a)(2) of EPCA. Plan Amendment No. 5 was transmitted by the Secretary to Congress on February 11,1999, and becomes effective on April 12, 1999.

\section{STATEMENT OF POLICY ON THE STRATEGIC PETROLEUM RESERVE}

On May 13, 1998, the Department of Energy issued the "United States Statement of Policy on the Strategic Petroleum Reserve" which reads as follows:

\section{Introduction}

In recognition of the comtimuing threat posed io 11.5 national security by a distuption in the flow of domestic or international petrolerm supplic's; the United States reaffirms its commilment lo mantam a Government-owned and controlled. ce'mtrally. located Strategic Petroleum Reserie (SP'R. or Resen'e) of crude oil. This Reserve shomld be used solely for responding to the trpes of se'vere onl supply interruptions presently contemplated in the Energy Policy and 'onsernation Act (EP'('A). The United States also reaffirms its policy for responding to severe oil supply disnuptions: Io re'ly. on market forces to allocate supply and io supplemem supply through an early drandewn of the SPR in large volumes and in coordination with our allies in the International Energy Agency. (IEA).

\section{Background}

On April 30, 1997, the Department of Energy published a Federal Register notice soliciting public comment examining the need for, appropriate use of, and operation of the SPR. This policy statement is the result of the Department 's internal review and evaluation of: the information submitted in response to the Federal Register notice. This policy is consistent with the FY 1998 budget, the FY 1998 budget agreement, and the Administration's FY 1999 budget request, and it reaffirms the Department's February 1994, "United States Policy for Responding to Oil Supply Disruptions.”

\section{Discussion}

Commitment to a Government-Owned, Government-Controlled Crude Oil Stockpile

The national, economic, and energy security interests of the United States remain vilnerable to the damaging effects of oil supply dismuptions. U.S. policy recognizes the best and perhaps only effective way to dampen the price rise and mitigate the economic damage resulting from a severe oil supply disruption -- damage that has contributed to three economic recessions in the past 25 years -- is to introduce additional. supplies into the market. While committed to the principles of the free market, we also have a keen appreciation that this is a role only the Federal Government can play' if w'e are to protect our nation's security in the elent of such disruptions.

The Administration is committed to the maintenance of an effective Government-owned and Government-controlled oil stockpile, with mechanisms in place to release those stocks on short notice. We would also note that the benefits of the Reserve are shared by all citizens. Therefore, the Reserve is properly a function of the 
Government and the costs should not be borne by industry or any narrow set of consumers. The Strategic Petroleum Reserve is a cornerstone of U.S. energy security policy. Accordingly, the Administration will work with Congress to ensure that sufficient inventory levels are maintained to provide the required degree of security.

\section{Use of the Reserve}

During a severe oil supply disruption the UI.S. will ordinarily supplement supply by the early drawdown of the Reserve in large volumes, in coordination with our IEA allies and will rely on market forces to distribute supply: It is essemial this policy be understood by our allies, the world market, and by potential actiersaries. If threatened by a severe oil supply intermuntom. "w' are prepared 10 use the Reserve and will do so as a matter of course', not by exception. The Reserv's is an essential componem of our national securn!. strategy, and its effective deplonme'll is guaranteed by having it Government-owned and controlled.

\section{Commitmem in International ('ooperanton on Energy' Security'}

We acknowledge the interdependence of our energy security with that of other major onl consuming nations and recognize that the he'nefits of any individual action taken in tumes of (n) shorlage by the Inited States will he e'mhemced considerably by coordination with our allie's and trading parmers. The Imited States is one of the founding members of the IE:A. The Agre'me'll om an International Energy Program, the charter of the IEA, commits its members to maincum the equivalent of 90 days of net oil imports as emergency reseries and io lake cooperatne' ac/lom in the event of an oil supply interruphom. H' reaffirm our active commitment wo work wh the other 23 member nations of the IEA to achieve our common energy security goals.

\section{Coverage of the Strategic Petroleum Reserve}

The inventory of crude oil stored in the Reserve peaked, in terms of days of net import coverage, in 1985 at 118 days. Coverage has since diminished as imports have increased and SPR inventory has been sold for non-emergency purposes, leaving the inventory in the Reserve in 1997 equal to 67 days of import protection. U.S. reliance on imported oil, currently nearing 50\% continues to rise and is expected to near $60 \%$ by the year 2010. At current inventory levels, the days of import protection provided by the Reserve will fall to $t 6$ days by 2005.

\section{The Changing World Oil Market}

The u'orld oil market has changed substantially in the last decade. The development of robust futures and options markets have made it possible for oil refiners, sellers and consumers to substitute financial instruments for dedicated sources of supply and to protect against the risks of price fluctuation. Oil has become a global commodity, and price changes are reflected through the world instantly. These developments have resulted in efficiencies and a general reduction of private sector companies 'operating inventories.

In addition, sources of world oil supply are more diverse than a decade ago, with significant growth in production coming from sources outside the Organization of Petroleum Exporting Countries and especially from the North Sea and Latin America. Meanwhile, the demand for oil continues 10 increase worlctwide, resulting in increased global competition for oil supplies.

The Administration believ'es that periodic reviews of the size of the SPR are a necessary part of an 
the business processes that support the core mission.

\section{PROGRAM AWARDS}

The Strategic Petroleum Reserve and DynMcDermott Petroleum Operations Company, its management and operating contractor, won several awards during this period. These awards were in the following categories:

\section{Quality}

- The Project Management Office won the Department of Energy's Quality Accomplishment Award in the 1998 Energy Quality Award competition. This award is two levels higher than the award won in 1997.

- For a second year in a row. DynMcDermott Petroleum Operations Company won the Department 's Champion Award in the 1998 competition.

\section{Environment, Safety, and Health}

- The Reserve won the Department of Energy's Pollution Prevention Award for a program to recover tank bottoms during tank cleaning, and to convert them into a liquid with a quality suitable for being returned to oil storage caverns.

- The Reserve won the Louisiana Governor's Environmental Leadership Award for its program to educate and involve on-site construction and service subcontractors in waste minimization and recycling activities 


\section{STORAGE PROGRAM}

STORAGE PROGRAM DESCRIPTION AND OBJECTIVES

The Strategic Petroleum Reserve developed six underground storage facilities between 1976 and 1991. The Sulphur Mines site was decommissioned in 1992 for cost savings, and the Weeks Island site is being decommissioned due to geotechnical problems. The remaining four sites are Bryan Mound and Big Hill in Texas, and West Hackberry and Bayou Choctaw in Louisiana.

The storage sites are organized into three distribution systems - Seaway, Texoma and Capline. Within each of these systems, the storage facilities have access to Gulf Coast refining centers, interstate crude oil pipelines, and one or more marine terminals for distribution (Figure 1).

FIGURE 1

STORAGE SITES AND DISTRIBUTION SYSTEM

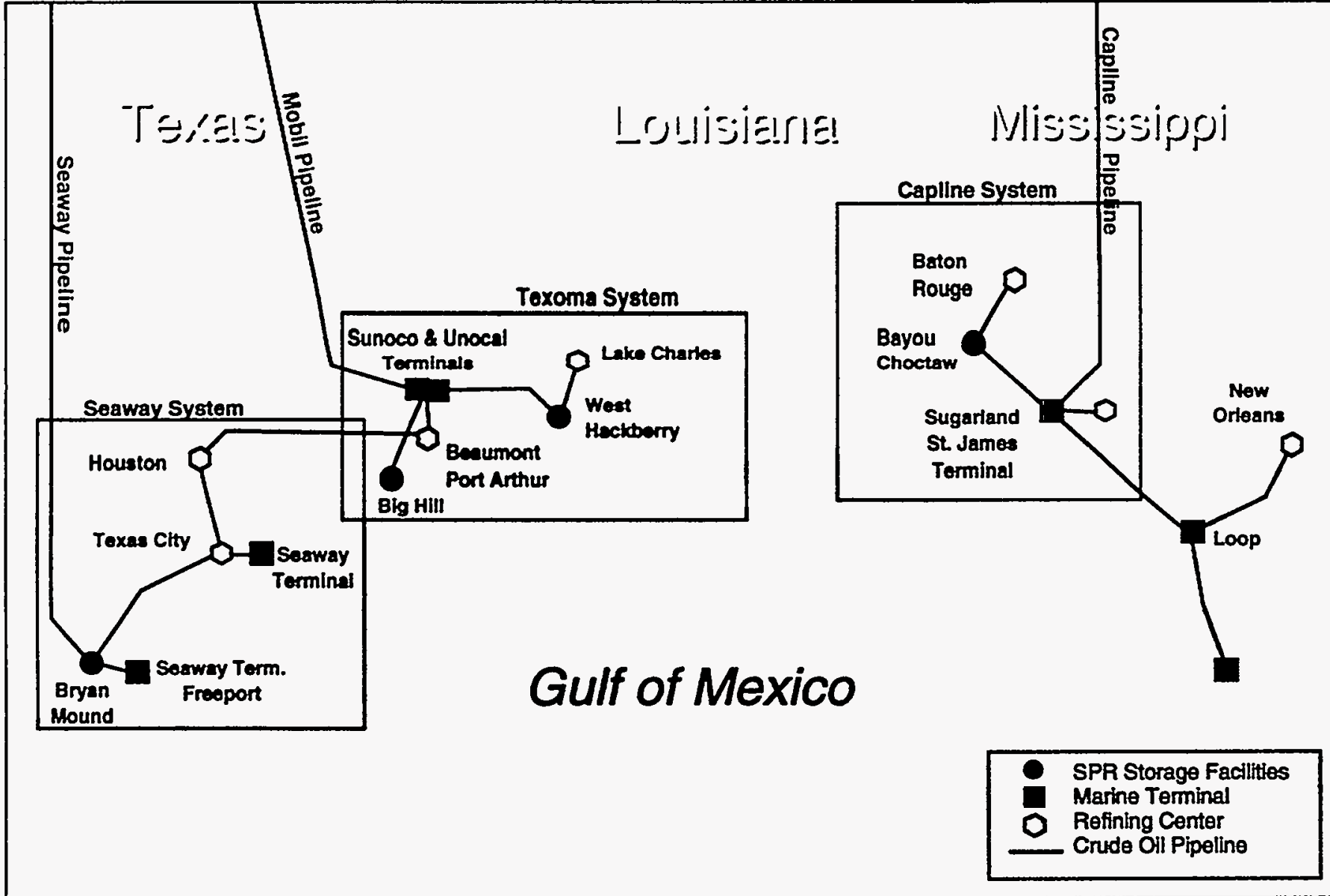

SPR2592.ppt 
As a result of the decommissioning of Weeks Island, the Reserve has lost 70 million barrels of capacity, reducing its overall storage capacity to 680 million barrels. However, during 1998, the Department reassessed the capacities of the remaining storage sites and estimates they are currently capable of storing 700 million barrels. This increase in capacity is a result of fresh water leaching of the caverns during the drawdown of oil in previous years, such as the Desert Storm drawdown activities, oil sales in 1995, 1996 and
1997, oil degassing movements and various site drawdown tests. As reported last year, the Department has minimized the loss of the Weeks Island drawdown capability by increasing the capabilities of the remaining sites under the current Life Extension Program. Table 1 summarizes the current changes in storage and drawdown capabilities of the storage facilities.

TABLE 1

STORAGE AND DRAWDOWN OBJECTIVES

\begin{tabular}{|c|c|c|c|c|c|c|}
\hline \multirow[b]{2}{*}{$\begin{array}{l}\text { Storage } \\
\text { Facility }\end{array}$} & \multicolumn{3}{|c|}{ PREVIOUS CONFIGURATION* } & \multicolumn{3}{|c|}{ CURRENT CONFIGURATION } \\
\hline & $\begin{array}{c}\text { Storage } \\
\text { Capacity } \\
\text { (MMB) }\end{array}$ & $\begin{array}{c}\text { Crude Mix } \\
\text { Sweet/Sour } \\
\text { (MMB) }\end{array}$ & $\begin{array}{c}\text { Drawdown } \\
\text { Capability } \\
\text { (MB/D) }\end{array}$ & $\begin{array}{l}\text { Storage } \\
\text { Capacity } \\
\text { (MMB) }\end{array}$ & $\begin{array}{c}\text { Crude Mix } \\
\text { Sweet/Sour } \\
\text { (MMB) }\end{array}$ & $\begin{array}{c}\text { Drawdown } \\
\text { Capability** } \\
\text { (MB/D) }\end{array}$ \\
\hline $\begin{array}{l}\text { Bryan } \\
\text { Mound }\end{array}$ & 226 & $66 / 160$ & 1.250 & 232 & $75 / 157$ & 1,500 \\
\hline $\begin{array}{l}\text { West } \\
\text { Hackberry }\end{array}$ & 219 & $113 / 106$ & 1.250 & 222 & $114 / 108^{-}$ & 1,300 \\
\hline Big Hill & 160 & $69 / 91$ & 430 & 170 & $72 / 98$ & $\begin{array}{l}1,100 \\
(9 / 00)\end{array}$ \\
\hline $\begin{array}{l}\text { Bayou } \\
\text { Choctaw }\end{array}$ & 75 & $24 / 51$ & 480 & 76 & $24 / .52$ & $\begin{array}{c}515 \\
(1 / 99) \\
\end{array}$ \\
\hline $\begin{array}{l}\text { Weeks } \\
\text { Island* }\end{array}$ & 70 & $0 / 70$ & 590 & - & - & - \\
\hline Total & 750 & $\begin{array}{c}272 / 478 \\
36^{\circ} \% / 64^{\circ} \circ\end{array}$ & +.500 & 700 & $\begin{array}{c}285 / 415 \\
40 \% / 60 \%\end{array}$ & 4,415 \\
\hline
\end{tabular}

* Prior To Wecks Island Decommissioning

** Drawdown Capabilities To Be Achieved B! (Month/Year)

Data as of December 31. 1998 


\section{FACILITIES LIFE EXTENSION PROGRAM}

To ensure continued mission readiness through the year 2025, a Life Extension Program was implemented in 1994 to upgrade or replace most major systems by the year 2000 , and streamline the facilities to reduce operating and maintenance costs. Revamped systems also incorporate the latest technologies to achieve higher reliability and availability.

Construction continues at all storage sites as the Life Extension Program enters its final stage of implementation. It remains on schedule for completion by the year 2000. Major milestones were achieved on schedule this year at Bryan Mound and West Hackberry when new drawdown systems were completed and tested.

During 1998, over $\$ 25$ million in contracts were awarded for equipment procurement and site construction, including contracts to purchase valves, wellheads, electrical equipment and security. equipment. Contracts were also awarded to begin integrated systems testing.

As of December 31, 1998, Bryan Mound and W'est Hackberry had approximately 95 percent of their projects in progress or completed, based on contract obligations made. Bayou Choctaw and Big Hill had approximately 93 percent and 84 percent, respectively, of their projects in progress or completed
The total estimated cost of the program is $\$ 328$ million, down by about $\$ 42$ million from its original estimate of $\$ 370$ million. Cost reductions have been effected by the deletion of projects planned for the Weeks Island site (to be decommissioned) and St. James Terminal (leased to Equilon Pipeline Corp.), and comprehensive value engineering efforts program-wide. Since 1994, the Department has obligated approximately $\$ 300$ million toward the Life Extension Program. Figure 2 shows the history of the Life Extension Program, including total estimated cost, annual budgets, and total obligations from 1994 to date. 


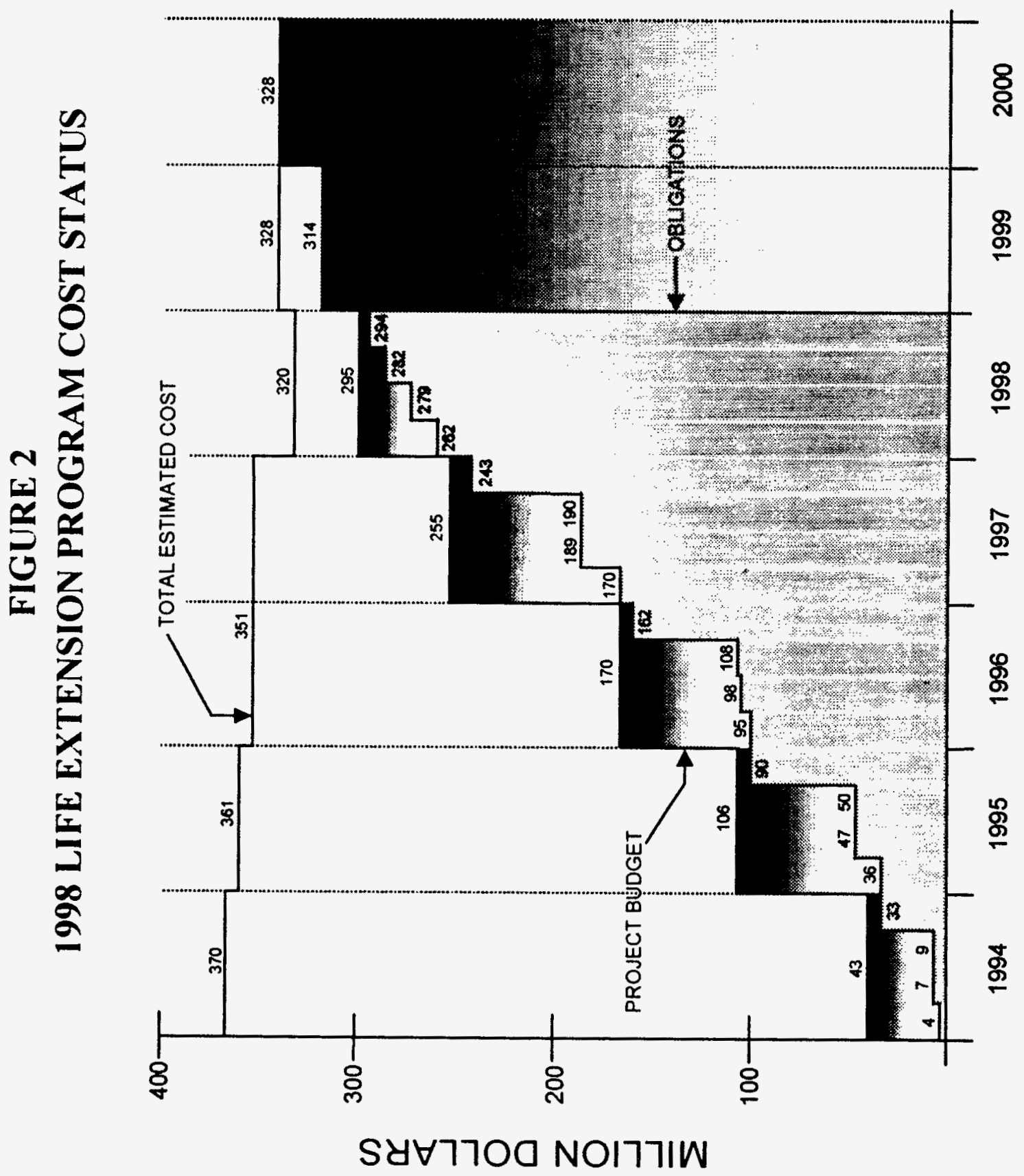




\section{STORAGE FACILITIES STATUS}

\section{BRYAN MOUND}

The Bryan Mound storage facility, located in Brazoria County, is approximately three miles southwest of Freeport, Texas. The site has twenty storage caverns, a combined storage capacity of 232 million barrels, and an inventory of 215 million barrels. The site is available for both fill and drawdown operations.

Under the Life Extension Program, the following projects were completed in August 1998:

- Construction of the new drawdown system, including installation of new water intake pumps, water injection pumps and header piping.

- Upgrades to the site's electrical system and replacement of the existing brine pond.

Construction to upgrade the site's crude oil refill and metering systems is underway and is about 40 percent complete.

In August 1998, a contract was awarded to replace the slop oil system and close the existing brine pond. This work is about 25 percent complete.

\section{WEST HACKBERRY}

The West Hackberry storage facility is located in Cameron Parish, approximately 22 miles southwest of Lake Charles, Louisiana. The site has twenty-two storage caverns, a combined storage capacity of 222 million barrels and an inventory of 193 million barrels. It is available for both fill and drawdown operations.

Under the Life Extension Program, the following projects were completed in September 1998:
- Construction of the new drawdown system, including new water intake pumps, water injection pumps and site header piping.

- Upgrades to the electrical system and replacement of the flush water system.

The replacement of the brine handling systems and brine ponds is about 95 percent complete.

In September 1998, contracts were awarded to upgrade the crude oil refill and metering systems, and close the existing brine pond.

\section{BAYOU CHOCTAW}

The Bayou Choctaw storage facility is located in Iberville Parish, approximately 12 miles southwest of Baton Rouge, Louisiana. The site has six storage caverns, a combined storage capacity of 76 million barrels and an inventory of 68 million barrels. The site is currently available for both fill and drawdown operations.

Under the Life Extension Program, construction that was initiated in 1997 to upgrade most of the major systems at Bayou Choctaw, including instrumentation and controls, piping reconfiguration, electrical system, valves and new water intake pumps, is approximately 70 percent complete.

\section{BIG HILL}

The Big Hill storage facility is located in Jefferson County, 20 miles southwest of Beaumont, Texas. The site has fourteen storage caverns, a combined storage capacity of 170 million barrels, and an inventory of 82 million barrels. The site is currently available for both fill and drawdown operations. Under the Life Extension Program, construction initiated in 1997 to upgrade most of the major systems at Big Hill, including instrumentation and 
controls, piping configuration, electrical system, valves and oil pumps, is approximately 60 percent complete.

\section{WEEKS ISLAND DECOMMISSIONING STATUS}

The Weeks Island facility is located in Iberia Parish, approximately 95 miles southwest of New Orleans, Louisiana. This site, a conventional salt mine, was acquired in 1977 and converted to an oil storage facility with a capacity of over 70 million barrels.

In December, 1994, the Secretary of Energy announced the decommissioning of Weeks Island due to geotechnical problems which posed a high risk of environmental damage and oil loss.

Decommissioning the site has involved removing the stored oil, filling the mine with brine to maintain stability, and skimming the remaining oil from the surface of the brine, in phases, as it is injected into the mine. The process began with most of the site's approximately 72 million barrel inventory being sold or transferred to other sites during 1995 and 1996. During 1998, approximately 54.7 million barrels of brine were injected into the mine, filling the lower level of the two-level mine. The multi-phase oil skimming operation that began in 1997 has thus far recovered over 2 million barrels of oil.

During 1999, the upper level of the mine will be filled with brine and final oil skimming will be undertaken. It is anticipated that some inventory may not be recoverable due to oil entrapment in the large volume of crushed salt residing on the mine floor and in traps in the roof.

Decommissioning activities continue with a projected completion date of December, 1999 . The service shaft, monitoring wells and the vent hole will be plugged, as required by the State of Louisiana. The surface facilities will be salvaged, removed, abandoned in place, or transferred to the General Services Administration for sale.

The Morton Salt Company owns the surrounding property and continues to mine salt. Formal mediation talks regarding the decommissioning plans were successfully completed in 1998 . The Department has agreed to assist Morton with the cost of mitigating risk in their operating shafts and safeguarding future mining operations.

\section{CRUDE OIL ACQUISITION, SALES, AND EXCHANGES}

\section{OIL SALE}

The Department of the Interior and Related Agencies Appropriations Act, 1998, required the Department of Energy to sell \$207.5 million worth of crude oil to offset that year's funding for the Reserve's activities. The Department developed plans to conduct a competitive sale in 1998, but Congress rescinded the sale requirement in the Emergency Supplemental Appropriations Act, enacted on May 1, 1998.

\section{MAYA CRUDE OIL EXCHANGE}

During 1998, the Department conducted an exchange of the 11 million barrels of Maya crude oil stored at the Bryan Mound site for 8.5 million barrels of other higher value crude oil.

The Maya crude oil was acquired from Mexico in the early 1980s, as part of a purchase agreement between the Department and Petroleos Mexicanos, Mexico's national oil company. Since that time, the Maya has been segregated in a single cavern at Bryan Mound because its lower API gravity and greater sulfur content made it significantly different from the other inventory. This had the effect of reducing the site's operational flexibility, efficiency, and drawdown capability during an energy emergency. 
On August 13, 1998, the Reserve solicited offers to deliver crude oil which would meet the Reserve's quality specifications, in exchange for the Maya. On August 27, 1998, the Reserve received offers from seven companies, and on August 28, an exchange contract was awarded to P.M.I. Norteamerico S.A. de C.V. of Houston, Texas. Subsequently, P.M.I. delivered a total of 8.5 million barrels of light sour Olmeca and Isthmus crude oils to Bryan Mound from October 1998 through early January 1999. In return, the Reserve transferred title of Maya ownership to P.M.I.; however, the Maya will remain in the custody of the Reserve until October 1999.

This exchange decreases the Reserve's total inventory by about 2.5 million barrels, but because of the higher quality of the oil received in the exchange, it does not decrease the value of the inventory. Additionally, it benefits the Reserve by increasing the quantity of Bryan Mound s light sour crude oil stream and improves the site's storage and drawdown capabilities.

\section{CRUDE OIL INVENTORY STATUS}

There were no oil acquisition activities during the calendar year 1998. As of December 31, 1998, the Reserve's crude oil inventory was 561,108,127 barrels. This fill level does not include the privately-owned Maya crude oil stored at the Bryan Mound site resulting from the exchange explained above.

The current mix of the Reserve's crude oil is 64 percent high sulfur (sour) and 36 percent low sulfur (sweet).

Table 2 illustrates year-end inventories and average daily fill rates from 1977 through 1998 (by fiscal and calendar year); Table 3 illustrates crude oil receipts by country of origin since 1977; Table 4 provides information on the location of this inventory by storage site; and Figure 3 illustrates the Reserve's cumulative oil fill. 


\section{TABLE 2}

YEAR-END INVENTORIES AND OIL FILL HISTORY

\begin{tabular}{|c|c|c|c|c|}
\hline & \multicolumn{2}{|c|}{ FISCAL YEAR } & \multicolumn{2}{|c|}{ CALENDAR YEAR } \\
\hline & $\begin{array}{l}\text { Year-End } \\
\text { Inventory } \\
\text { (MMB) }\end{array}$ & $\begin{array}{l}\text { Average Daily } \\
\text { Fill Rate } \\
\text { (MB/D) }\end{array}$ & $\begin{array}{c}\text { Year-End } \\
\text { Inventory } \\
\text { (MMB) }\end{array}$ & $\begin{array}{c}\text { Average Daily } \\
\text { Fill Rate } \\
\text { (MB/D) }\end{array}$ \\
\hline 1977 & $1: 1$ & 3 & 7.2 & 20 \\
\hline 1978 & 49.1 & 131 & 68.5 & 168 \\
\hline 1979 & 91.2 & 115 & 91.7 & 64 \\
\hline i 980 & 92.8 & 4 & 107.8 & 44 \\
\hline 1981 & 199.2 & 292 & 230.3 & 336 \\
\hline 1982 & 277.9 & 215 & 293.8 & 174 \\
\hline 1983 & 361.0 & 228 & 379.1 & 234 \\
\hline 1984 & 431.1 & 191 & 450.5 & 195 \\
\hline 1985 & 489.3 & 159 & 493.3 & 119 \\
\hline 1986 & 506.4 & 47 & 511.6 & 51 \\
\hline 1987 & 533.9 & 75 & 540.6 & $80^{\circ}$ \\
\hline 1988 & 554.7 & 57 & 559.5 & 52 \\
\hline 1989 & 577.1 & 62 & 579.9 & 56 \\
\hline 1990 & 589.6 & 34 & 585.7 & 27 \\
\hline 1991 & 568.5 & (58) & 568.5 & $(47)$ \\
\hline 1992 & 571.4 & 8 & 574.7 & 17 \\
\hline 1993 & $\mathbf{5 8 5 . 7}$ & 39 & 587.1 & 34 \\
\hline 1994 & 591.7 & 16 & 591.7 & 13 \\
\hline 1995 & 591.7 & $\approx *$ & 591.6 & $\star \star$ \\
\hline 1996 & 573.6 & (49) & 565.8 & (70) \\
\hline 1997 & 563.4 & (28) & 563.4 & (7) \\
\hline 1998 & 563.4 & ** & 561.1 & 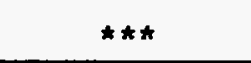 \\
\hline
\end{tabular}

* Fill rates adjusted for oil sales.

** Fill suspended during this period

*** Decrease due to Maya exchange

Data as of December 31. 1998 
TABLE 3

CRUDE OIL RECEIPTS THROUGH 1998 (MILLION BARRELS)

\begin{tabular}{|c|c|c|c|}
\hline Source Country & 1998 & Cumulative & Percent of Total \\
\hline Mexico* & 8.5 & 254.2 & 41.7 \\
\hline United Kingdom & & 147.3 & 24.1 \\
\hline United States & & 48.1 & 7.9 \\
\hline Saudi Arabia & & 27.1 & 4.4 \\
\hline Libya & & 23.7 & 3.9 \\
\hline Iran & & 20.0 & 3.3 \\
\hline United Arab Emirates & & 18.4 & 3.0 \\
\hline Nigeria & & 15.1 & 2.5 \\
\hline Norway & & 11.9 & 2.0 \\
\hline Oman & & 9.0 & 1.5 \\
\hline Egypt & & 8.9 & 1.5 \\
\hline Ecuador & & 6.2 & 1.0 \\
\hline Algeria & & 6.2 & 1.0 \\
\hline Cameroon & & 3.4 & 0.6 \\
\hline Iraq & & 3.4 & 0.6 \\
\hline Gabon & & 2.4 & 0.4 \\
\hline Qatar & & 2.3 & 0.4 \\
\hline Angola & & 1.0 & 0.2 \\
\hline Vencruela & & 0.9 & 0.1 \\
\hline Peru & & 0.4 & 0.1 \\
\hline Argentina & & 0.4 & 0.1 \\
\hline TOTAL RECEIPTS** & 8.5 & 610.3 & 100.0 \\
\hline
\end{tabular}

* Cumulative receipts from Mexico adjusted to reflect exchange of Mava crude oil.

* Cumulative total receipts unadjusted for sales and operational gains and losses.

Data as of December 31. 1998 
TABLE 4

STRATEGIC PETROLEUM RESERVE

CRUDE OIL INVENTORY

\begin{tabular}{|c|c|c|c|c|}
\hline \multirow{2}{*}{ Storage Site } & \multicolumn{3}{|c|}{ Inventory (Millions of Barrels) } & \multirow{2}{*}{$\begin{array}{c}\text { Cubic } \\
\text { Meters } \\
\text { (Millions) }\end{array}$} \\
\hline & Sweet* & Sour ${ }^{\star \star}$ & Total & \\
\hline $\begin{array}{l}\text { Bryan Mound }{ }^{* * *} \\
\text { Brazoria County, Texas }\end{array}$ & 62.2 & 152.7 & 214.9 & 34.2 \\
\hline $\begin{array}{l}\text { Big Hill } \\
\text { Jefferson County, Texas }\end{array}$ & 18.8 & 63.1 & 81.9 & 13.0 \\
\hline $\begin{array}{l}\text { West Hackberry } \\
\text { Cameron Parish, Louisiana }\end{array}$ & 103.9 & 89.4 & 193.3 & 30.7 \\
\hline $\begin{array}{l}\text { Weeks Island } \\
\text { Iberia Parish, Louisiana }\end{array}$ & 0 & 1.5 & 1.5 & 0.2 \\
\hline $\begin{array}{l}\text { Bayou Choctaw } \\
\text { Iberville Parish, Louisiana }\end{array}$ & 17.3 & 50.4 & 67.7 & 10.8 \\
\hline $\begin{array}{c}\text { Subtotal } \\
\text { Underground Inventory }\end{array}$ & 202.2 & 357.1 & 559.3 & 88.9 \\
\hline Tanks and Pipelines & 0.1 & 1.7 & 1.8 & 0.3 \\
\hline $\begin{array}{c}\text { Total } \\
\text { Inventory }\end{array}$ & 202.3 & 358.8 & 561.1 & 89.2 \\
\hline
\end{tabular}

* Sulfur content not exceeding 0.5 percent

** Sulfur content greater than 0.5 percent

*** The site additionally holds 10.3 million barrels of privately-owned Maya crude oil.

**** Site being decommissioned

Data as of December 31, 1998 


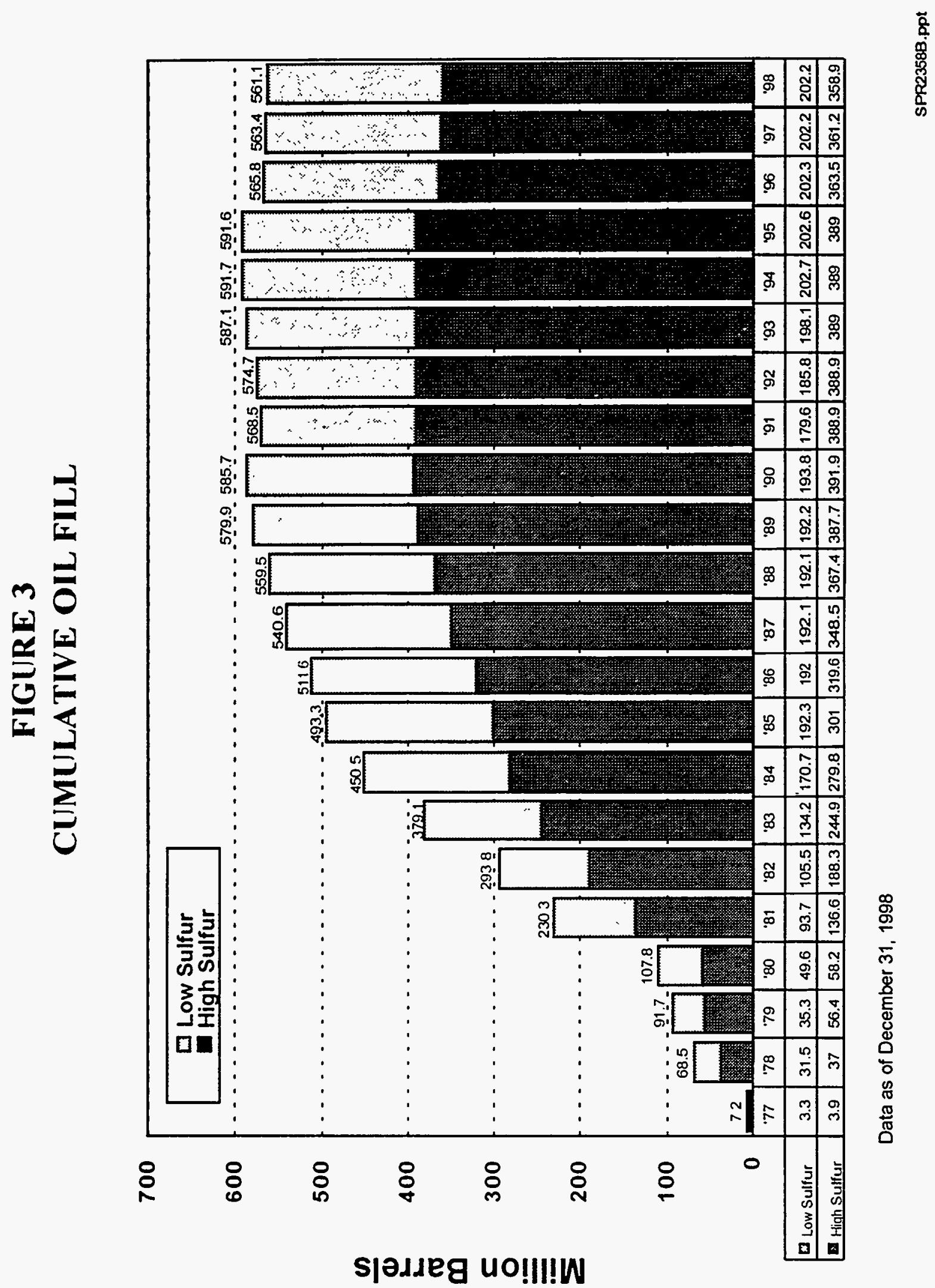


Strategic Petroleum Reserve Annual Report 1998

\section{EMERGENCY RESPONSE CAPABILITIES}

\section{DRAWDOWN AND DISTRIBUTION PLAN}

The current method for distributing crude oil is described in the "Strategic Petroleum Reserve Drawdown (Distribution) Plan," Amendment Number 4 to the Strategic Petroleum Reserve Plan. The principal method for distributing oil is by price competitive sale. The sale is open to the largest possible universe of eligible buyers to ensure economically and operationally efficient distribution.

The Plan also provides for the Secretary of Energy to direct, in any calendar month, the distribution of up to 10 percent of the volume of oil sold in that calendar month. The price for such oil will be the average price of oil sold at the contemporaneous competitive sale, or at the most recent competitive sale if no contemporaneous competitive sale is held.

\section{COMPETITIVE SALES PROCEDURES}

The Department's Standard Sales Provisions* govern the competitive sales process. The first step in the process is the issuance of a Notice of Sale which identifies the volume, characteristics, and location of the petroleum for sale, delivery dates. and procedures for submitting offers. Measures required for assuring performance and financial responsibility are also described in the Notice of Sale.

* Department of Energy, 10 CFR Part 625. Price Competitive Sale of Strategic Petroleum Reserve Petroleum; Standard Sales Provisions. The most recent edition of the Standard Sales Provisions was published in the Federal Register on October 8 , 1998 (63 FR 54196).
Over the course of a drawdown, several Notices of Sale may be issued, each covering a sales period of one to two months. Offerors may have only seven days from the date of a Notice of Sale is issued until offers are due, and thirty days or less until purchasers must begin accepting delivery of the oil. A less compressed schedule may become more feasible in subsequent sales periods. Because of the possible short initial lead time, the Department maintains a list of prospective offerors who will receive all Notices of Sale and intends to make maximum use of electronic communication to effect Notice of Sale distribution.

The next step in the sales process is for prospective purchasers to submit offers, as specified in the Notice of Sale. Offerors must accept unconditionally all terms and conditions in the Notice of Sale, submit an offer guarantee of 5 percent of the maximum potential contract amount or $\$ 10$ million, whichever is less, and offer at least the minimum price, if any is specified in the Notice of Sale. The offer evaluation process is structured so that the offerors bidding the highest prices determine the transportation methods, up to the limits of the distribution system. Specific delivery arrangements are negotiated later in the process.

All "apparently successful offerors" are required, within five business days of being notified, to provide a Letter of Credit equal to 100 percent of the contract amount as a guarantee of performance and payment of amounts due under the contract. Upon timely receipt of the financial guarantees, and a final determination by the Contracting Officer that offers were responsive and offerors responsible, Notices of Award are issued. Deliveries to the purchasers may then begin, consistent with their arrangements for commercial 
pipeline or marine vessel transportation. Such deliveries may begin as soon as the 16th day of the sales process, to the extent that the purchasers have submitted their financial guarantees and can arrange timely transportation.

\section{DRAWDOWN CAPABILITIES}

The crude oil acquired for the Strategic Petroleum Reserve has been commingled in storage at the storage sites, creating various distinct crude oil streams to be made available for sale during a drawdown. Table 5 identifies these streams, delivery modes and locations, as of December 31 , 1998.

The Reserve is capable of being drawn down at an initial sustainable rate of 4.05 million barrels per day for a period of 90 days. After the initial 90-day period, the drawdown rate will decrease gradually as site inventories are depleted and the declining number of caverns containing crude oil becomes a constraint. Figure 4 illustrates the end-of- 1998 physical drawdown capability which provides for a distribution of 368 million barrels in 90 days, and 550 million barrels in 180 days.

The 1998 initial sustainable drawdown rate of 405 million barrels per day is higher than the 1997 rate of 3.7 million barrels per day due to the installation of heat exchangers at Big Hill, completion of raw water intake structure work at West Hackberry. and completion of related Life Extension activities at Bryan Mound and West Hackberry The completion of Life Extension Program activities at all sites will ultimately stabilize the initial sustainable drawdown capability for the current total inventory at 4.1 million barrels per day 


\section{TABLE 5 \\ CRUDE OIL STREAMS}

\begin{tabular}{|c|c|}
\hline Crude Oil Stream & Delivery Mode and Location \\
\hline \multicolumn{2}{|l|}{ SEAWAY GROUP: } \\
\hline Bryan Mound Sweet & \multirow{2}{*}{$\begin{array}{l}\text { Pipeline or tankship at Seaway Terminal, Freeport, Texas: or } \\
\text { Seaway. Terminal, Texas City, Texas }\end{array}$} \\
\hline Bryan Mound Sour & \\
\hline \multicolumn{2}{|l|}{ TEXOMA GROUP: } \\
\hline West Hackberry Sweet & \multirow{2}{*}{$\begin{array}{l}\text { Pipeline. tankship or barge at Sunoco Terminal, Nederland Texas; } \\
\text { Pipeline at Equilon-22"/DOE connection, Lake Charles, Louisiana }\end{array}$} \\
\hline West Hackberñ Sour & \\
\hline Big Hill Sweet & \multirow{2}{*}{$\begin{array}{l}\text { Pipeline. tankship or barge at Sunoco Terminal, Nederland, Texas; } \\
\text { Pipeline or tankship at Unocal Terminal, Nederland, Texas; } \\
\text { Pipeline at Equilon-20"/DOE connection, Winnie. Texas }\end{array}$} \\
\hline Big Hill Sour & \\
\hline \multicolumn{2}{|l|}{ CAPLINE GROUP: } \\
\hline Bayou Choctaw Sweet & \multirow{2}{*}{$\begin{array}{l}\text { Pipeline at Caplıne or LOCAP Terminals. St. James. Louisiana; } \\
\text { Tankshıp at Sugarland St. James Terminal. St. James, Louisiana }\end{array}$} \\
\hline Bayou Choctaw Sour & \\
\hline
\end{tabular}

Data as of December 31. 1998 


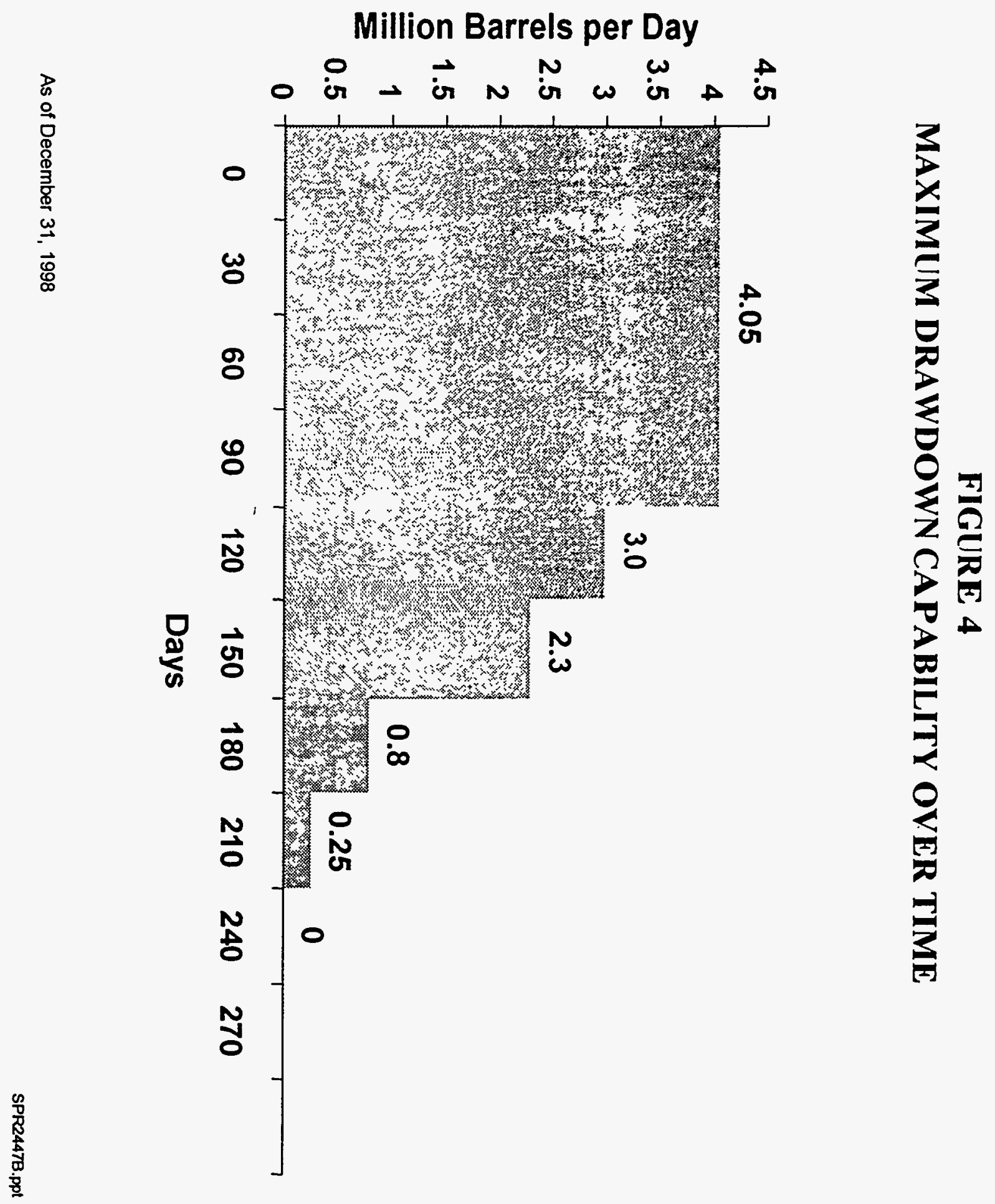




\section{DRAWDOWN READINESS ACTIVTTIES}

The Strategic Petroleum Reserve continues to ensure its readiness for drawing down and selling crude oil. Drawdown readiness assurance activities during 1998 included:

- Conducting periodic assessments, including some by external sources, of the readiness and availability of all functions, facilities, including commercial distribution terminals, and systems associated with a drawdown.

- Demonstrating the West Hackberry site's improved drawdown system capability through a physical oil movement.

- Performing a series of exercises to validate the internal processes and procedures, both at the Headquarters and field level, for conducting a drawdown, sale, and delivery of Strategic Petroleum Reserve oil.

- Analyzing and updating the drawdown and distribution capabilities to reflect improvements resulting from completed life extension activities.

- Completing a comprehensive flowchart of the various activities performed during the drawdown and sale process which provides a basis for training, future exercises, and possible process re-engineering

- Publishing in the Federal Register on October 8, 1998, a revision to the Department's Standard Sales Provisions for the sale of Strategic Petroleum Reserve petroleum.
- Developing plans for a training exercise to perform the various functions associated with scheduling and documenting oil deliveries to purchasers, as well as administering the purchase contracts.

\section{DISTRIBUTION PLAN AND CAPABILITIES}

The Strategic Petroleum Reserve is connected to both commercial pipeline systems and marine terminals for crude oil distribution to U.S. refiners in the event of an energy emergency.

The Reserve's drawdown and distribution capabilities are summarized in Table 6. These capabilities are based on the current crude oil stream inventories, the existing site drawdown systems and commercial distribution capabilities.

The Reserve is currently accessible to 19 refiners in the Gulf Coast and 28 refiners in the Midcontinent and Midwest, respectively, through local and interstate pipelines. These 47 refiners comprise approximately 49 percent of the total U.S. refining capacity, and in 1998, they. processed over 57 percent of the U.S.'s crude oil imports.

The Reserve is also connected to five marine terminals for waterborne distribution: Seaway (Phillips) Terminal in Freeport, Texas; Seaway (ARCO) Terminal in Texas City, Texas; Sunoco and Unocal Terminals in Nederland, Texas; and Sugarland St. James Terminal in St. James, Louisiana. These terminals have a total of 13 tanker berths and three barge berths, and a combined distribution capacity of approximately 2.5 million barrels per day. Figure 5 shows the Reserve's pipeline and marine distribution capabilities. 
TABLE 6 DRAWDOWN AND DISTRIBUTION CAPABILITIES
(THOUSANDS OF BARRELS PER DAY)

\begin{tabular}{|l|c|c|}
\cline { 2 - 3 } \multicolumn{1}{c|}{} & Drawdown & Distribution \\
\hline Seaway Group & 1,500 & 2,150 \\
\hline Texoma Group & 2,070 & 3,090 \\
\hline Capline Group & 480 & 825 \\
\hline \hline TOTAL & 4,050 & 6,065 \\
\hline
\end{tabular}

Data as of December 31. 1998 
FIGURE 5

PIPELINE AND MARINE DISTRIBUTION CAPABILITIES

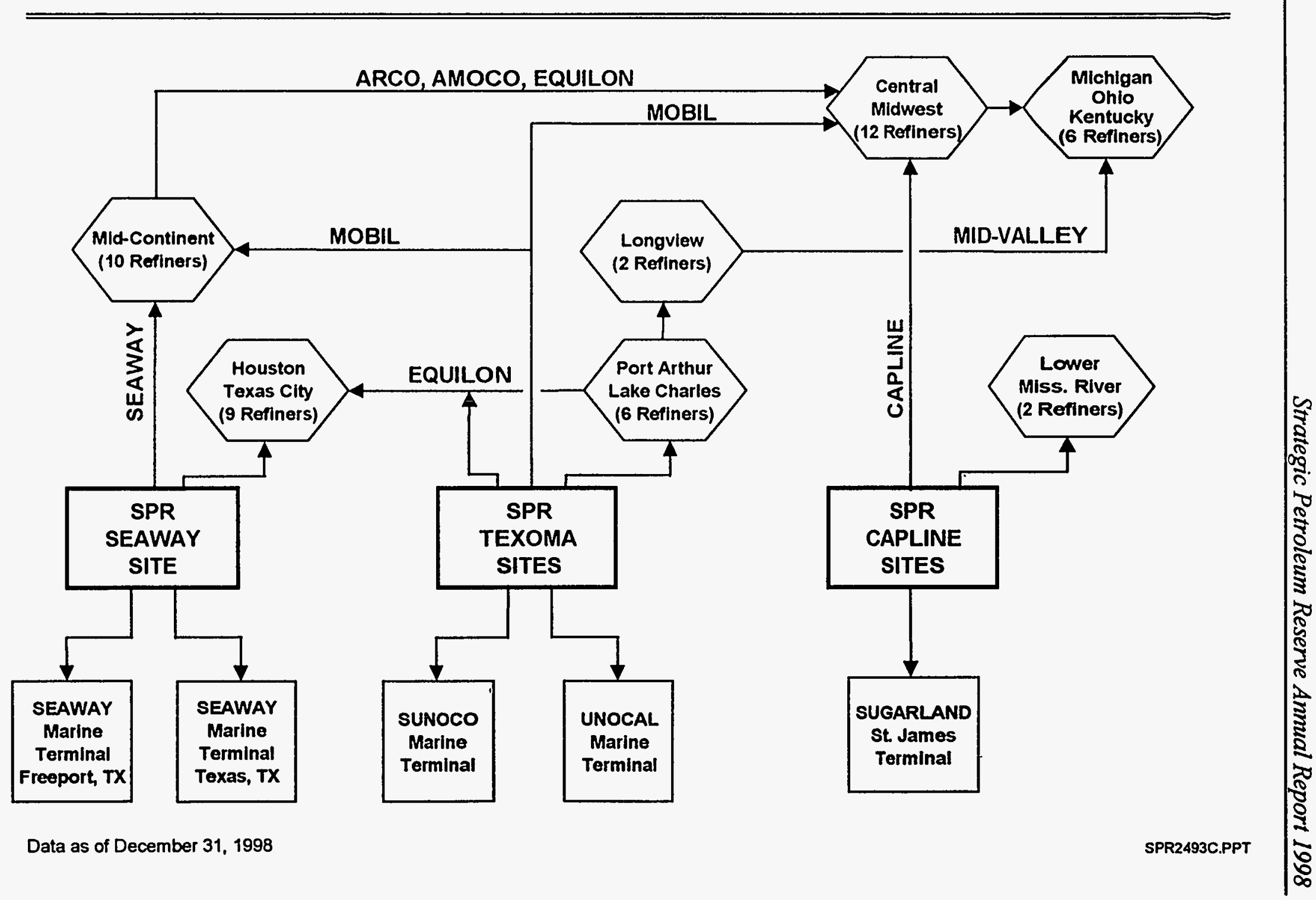




\section{DISTRIBUTION ASSESSMENT}

A comprehensive assessment was made of the present and projected capabilities of the commercial pipeline distribution systems to distribute the Reserve's crude oil to the refining industry, in the event of a drawdown. The purpose of this assessment was to ensure there are adequate connections to the commercial distribution systems, and to identify the need to develop any remedial plans, if appropriate.

The assessment evaluated the Strategic Petroleum Reserve's capability to sustain its maximum drawdown rate in 1998, 2000 and 2005, based on future U.S. petroleum refining demands as forecasted in EIA's Anmual Energy' Outlook. 1998.

The assessment incorporated numerous changes which have been made to commercial pipeline distribution systems in the last few years the Seaway Pipeline conversion to crude service in 1996; the Mobil pipeline reversal in 1997 for moving oil from Beaumont, Texas to Cushing. Oklahoma, and Patoka, Illinois; and the conversion of several crude pipelines from Houston. Texas to the Midcontinent to refined product operations It also reviewed the impact of the increasing deep water domestic production in the Gulf of Mexico. and the issue of increasing foreign ownership and supply agreements of U.S. refineries

Finally, the assessment confirmed that the Strategic Petroleum Reserve has sufficient offsite distribution capabilities (defined as 120 percent of the maximum drawdown rate) to achieve the current. and year 2000, drawdown rates.

\section{EMERGENCY RESPONSE CAPABILITIES}

The Strategic Petroleum Reserve was established by the Energy Policy and Conservation Act to reduce the impact of disruptions in petroleum supplies, and to meet U.S. obligations under the International Energy Program. In the Act, Congress specified an initial storage objective equal to 90 days of net petroleum imports, which equated to a 500 million barrel Reserve in 1976.

As of December 31, 1998, the inventory of crude oil in the Reserve was approximately 561 million barrels. This stockpile provides an import protection level of 60 days, based on the U.S. net import rate for crude and petroleum products during 1998. As shown in Figure 6, the level of net import protection has continued in a declining trend over the last thirteen years, due to the U.S.'s increasing dependence on oil imports, depicted in Figure 7.

The United States, as a member nation of the International Energy Program, is committed to maintaining stocks of crude and products in reserves "sufficient to sustain consumption for at least 90 days with no net oil imports." For the International Energy Program, computations of member stocks are based on both public and privately-held stocks, and net imports are defined to be the average daily level in the previous year. The most recent International Energy Program computation for the United States credits the United States with 155 days of emergency reserves, including both Reserve and privately held stocks. 
FIGURE 6

DAYS OF NET IMPORT PROTECTION (1977 - 1998)

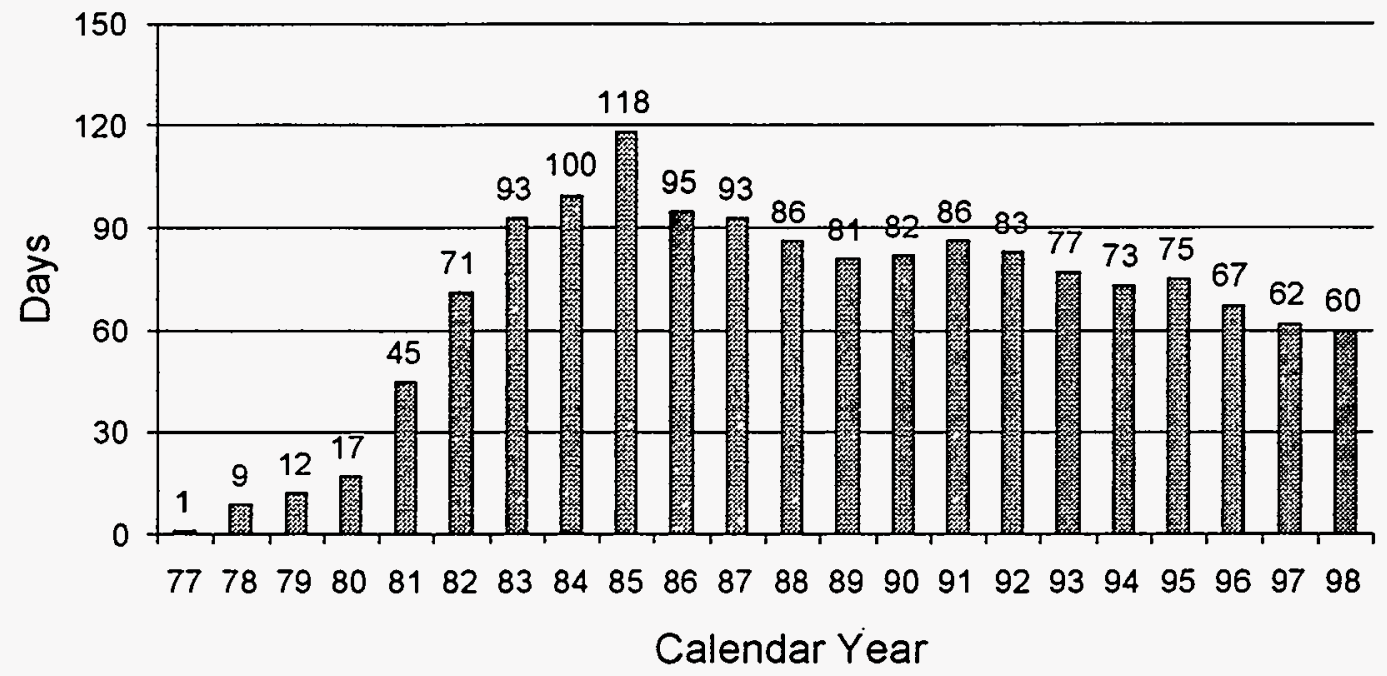

NOTE Data as of December 311998 reflects the year-end Strategic Petroleum Reserve inventory. drvided by the average dail, US net imports for that year

FIGURE 7

U.S. NET CRUDE AND PRODUCT IMPORTS (1977 - 1998)

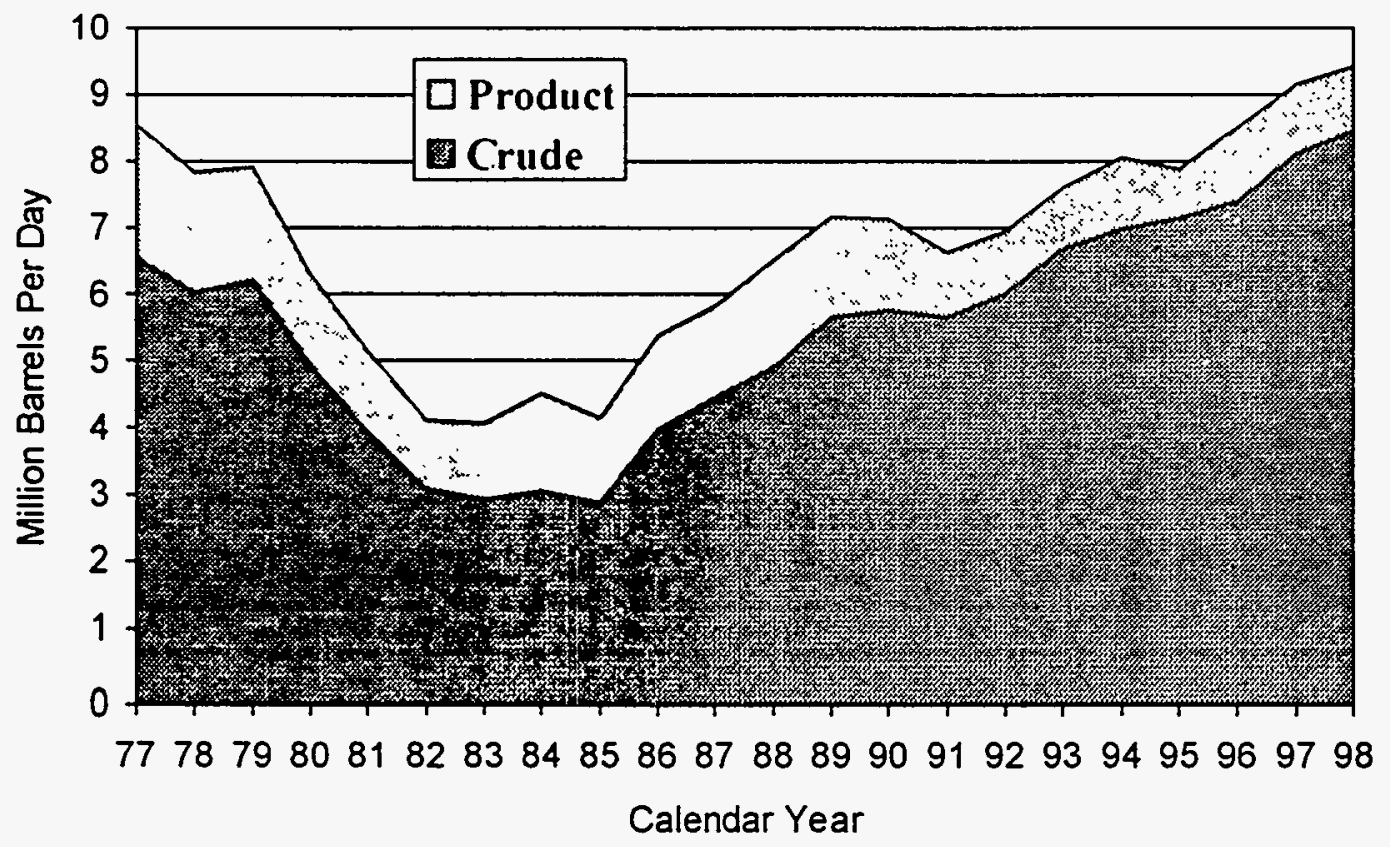




\section{COMMERCLALIZATION ACTIVITIES}

\section{DEPARTMENT POLICY AND OBJECTIVES}

Under Section 159(f)(D) of the Energy Policy and Conservation Act, the Secretary of Energy has statutory authority to "use, lease, maintain, sell or otherwise dispose of storage and related facilities." Since 1995; the Department has successfully used this authority to lease or outgrant the use of its underutilized distribution facilities for the purpose of reducing operational costs and generating revenues, while retaining the ability to use these facilities in the event of a national energy emergency. The Government contracts for these leases provide that the facilities will be maintained in good condition, and that, with notice. the Government will have priority for the emergency drawdown of oil from the Strategic Petroleum Reserve.

In 1997, the President signed the Balanced Budget Act of 1997 (Public Law 105-33) which amended the Energy Policy and Conservation Act to provide explicit authority to the Secretary of Energy to lease unused storage capacity within the Strategic Petroleum Reserve to foreign governments or their representatives. The Department supports the storage of foreign or commercial oil in the Reserve's unused storage capacity The leasing authority for the storage of either foreign or commercial customers promotes world oil stockpiling, which contributes to both US and world energy security.

During 1998, the Department pursued both foreign and commercial storage initiatives with the objective of acquiring oil for the Reserve in lieu of payment. In this way, the Department should be able to increase the Reserve's fill level without Federal funding.

\section{COMMERCLAL LEASES OF DISTRIBUTION FACIILITIES}

Over the last three years, the Strategic Petroleum Reserve has successfully commercialized its marine terminal in St. James, Louisiana, and three of its five major crude pipelines, by leasing them to industry for commercial crude oil operations. These commercialization efforts have reduced the annual operational costs of the Reserve and generated revenues for the U.S. Treasury, while retaining the capability to use these facilities in the event of a national energy emergency.

\section{ST. JAMES TERMINAL}

The Reserve's St. James terminal, constructed in 1980, has six storage tanks and two tanker docks located on the west bank of the Mississippi River at St. James, Louisiana. The St. James Terminal was leased to Shell Pipe Line Corporation (now Equilon Pipeline Company) on January 31, 1997 , on a revenue-sharing basis. The leasing of this facility has provided an annual operational cost savings to the Reserve of $\$ 6$ to $\$ 7$ million per year. During 1998, the Government received $\$ 469,059$ in lease revenues from the terminal.

\section{BAYOU CHOCTAW PIPELINE}

The Bayou Choctaw pipeline is a 37-mile, 36 -inch pipeline extending from the Bayou Choctaw storage facility in Plaquemine, Louisiana to marine facilities in St. James. This pipeline was leased to Shell Pipe Line Corporation (now Equilon Pipeline Company) on May 1, 1997, on a revenue-sharing basis. During 1998, the Department modified the lease from a year-to-year to a 10-year lease, and Equilon initiated the construction of a 17-mile 
extension to the pipeline for crude movements to the Baton Rouge area. The Government will start receiving lease revenues from the pipeline when it begins commercial operations in early 1999.

\section{BIG FILL PIPELINE}

The Big Hill pipeline is a 24.4-mile, 36-inch pipeline extending from the Big Hill storage facility near Winnie, Texas to marine facilities in Nederland, Texas. A 7.5 mile segment of this pipeline was leased to Texaco Pipe Line Incorporated (now Equilon Pipeline Company) on October 15, 1997, under a 75 percent capacity lease contract. During 1998, the Government received $\$ 402,525$ in lease revenues from the pipeline.

\section{BRYAN MOUND PIPELINES}

The Bryan Mound storage site has three connecting pipelines: a 46-mile, 40-inch pipeline to Texas City. a 4-mile, 30-inch pipeline to Seaway's Jones Creek Tank Farm, and a 3.9-mile, 30-inch pipeline to Seaway's marine docks at Freeport. Texas. During 1998, the Reserve negotiated and awarded two leases for Texas City and Jones Creek segments. A short-term (6-month) lease was awarded to the Seaway Pipeline Company on December 11. 1998 and will be used to move crude oil from Seaway's Texas City facility to its Jones Creek facility, while its storage tanks are out of service for maintenance A long-term $(10+$ year) lease was awarded to Exxon Pipeline Company in January 1999 Under this lease, Exxon will use the Texas City and Jones Creek pipeline segments, starting in July 2000, as part of its onshore distribution system for Exxon's Diana-Hoover production in the Gulf of Mexico

\section{WEST HACKBERRY PIPELINES}

The West Hackberry storage site has two connecting pipelines: a 42.8-mile, 42-inch pipeline from the West Hackberry storage site to Nederland,
Texas and a 13.6-mile, 36-inch pipeline from the West Hackberry storage site to Lake Charles, Louisiana. Neither of these pipelines has been leased due to the lack of industry interest in these facilities.

\section{FOREIGN OIL STORAGE CAPABILITIES AND ACTIVTTIES}

The Big Hill storage facility has the capacity to store 170 million barrels of crude oil and currently contains 82 million barrels of oil. During 1998, the Department continued to offer to store foreignowned oil of both consuming and producing countries in the underutilized caverns at Big Hill. The unused storage space provides an opportunity to increase world oil stockpiling, add oil to the U.S. Reserve in lieu of a lease fee, or generate additional revenue for the U.S. Treasury. The Balanced Budget Act of 1997 (Public Law 105-33), which was enacted on August 5, 1997, provides specific authority to store petroleum product owned by another country, or its representative, in the Strategic Petroleum Reserve, provided that the U.S. is fully compensated for all related costs of storage and that the ability to draw down U.S. oil is not impaired.

On September 22, 1998, the Big Hill storage site was activated as a foreign trade zone subzone. A foreign trade zone is a site within the United States, in or near a U.S. Customs port of entry, where foreign and domestic merchandise is considered to be in international commerce. This designation, which permits customers to store oil without paying customs fees and certain taxes, is expected to enhance the Department's offer to store oil for foreign governments, or their representatives. The Department of Energy is the first government entity to receive foreign trade zone designation for one of its facilities.

The Department worked closely with authorities of Port Arthur, the Department of Commerce and the 
United States Customs Service in seeking foreign trade zone subzone status for Big Hill.

\section{WEST HACKBERRY COMMERCIAL STORAGE INITIATIVE}

The surplus oil market during the first half of 1998 , resulted in low oil prices and a lack of commercial storage facilities within the U.S. The Department initiated a concept whereby it would store commercially-owned crude oil in unused storage capacity, for a fee, to be paid in oil, which would be stored in the Reserve. In this manner, the Department would be able to increase the Reserve's fill level without Federal funding.

On July 23, 1998, the Department issued a solicitation to the oil industry seeking weekly offers to store up to 20 million barrels at the West Hackberry storage site for a minimum period of six months. However, due to changing market conditions and the fact that the domestic pipeline and terminalling systems were operating at full capacity, preventing prospective offerors from economically delivering oil to the West Hackberry site, no offers were received. Consequently, the solicitation was cancelled in September

The Department continues to explore similar opportunities that should result in additional oil for the Reserve. On February 17. 1999, a solicitation was issued requesting offers to store up to 70 million barrels at the Big Hill site for a minimum of one year. 
Strategic Petroleum Reserve Annual Report 1998

\section{BUDGET AND FINANCE}

The Department of the Interior and Related Agencies Appropriations Act, 1998, provided $\$ 207.5$ million for Strategic Petroleum facilities operations and management.

The Department of the Interior and Related Agencies Appropriations Act, 1999, provided $\$ 160.1$ million for Strategic Petroleum Reserve facilities operations and management.

\section{APPROPRIATIONS THROUGH FISCAL YEAR 1998}

A total of $\$ 21.0$ billion, net of sales and transfers. has been appropriated for the Strategic Petroleum Reserve through fiscal year 1998. Included in this total are the distribution of annual and total appropriations described in Table 7 . Figure 8 illustrates the cumulative appropriations for storage facilities operations and management, as well as petroleum acquisition and transportation.

\section{STRATEGICPETROLEUMRESERLE AC'OUUNT}

The Strategic Petroleum Reserve Account funds the development, operation, and maintenance of Reserve facilities; the salaries and expenses necessary to plan and manage the program. including the operation of the Project Management Office in New Orleans, Louisiana; and the activities pertinent to major issues concerning the development and use of the Strategic Petroleum Reserve.

Obligations for the Strategic Petroleum Reserve in fiscal year 1998 totaled approximately $\$ 212.9$ million. From this amount, $\$ 16$ million was obligated for federal program management salaries and benefits, and $\$ 196.9$ million was obligated for contractual goods and services to operate and maintain the Reserve. The remaining $\$ 36.6$ million available for obligation at the end of fiscal year 1998 was associated with Life Extension program awards, which slipped to early fiscal year 1999 , Weeks Island decommissioning obligations, which slipped to early fiscal year 1999 , construction changes and claims, and workload rescheduled from late fiscal year 1998 to early fiscal year 1999. Also included in these carryover balances is approximately $\$ 1$ million associated with the Expansion Study, which was suspended in 1993. These funds have been reported available for rescission after Congress rescinds the requirement to complete the Plan to expand storage capability to 1 billion barrels.

\section{SPR PETROLEUM ACCOUNT}

The SPR Petroleum Account funds the acquisition of oil for the Strategic Petroleum Reserve; the associated costs for transportation and terminalling; U.S. customs duties, Superfunds and Oil Spill Liabilities Trust Fund taxes; and other miscellaneous costs, such as Defense Energy Support Center administration costs associated with non-emergency sales, as well as oil acquisition, and transportation support. During an emergency drawdown and sale, the SPR Petroleum Account is the source of funding for the incremental costs of withdrawing oil from the storage caverns and transporting it to the point where purchasers take title. During an emergency drawdown and sale, an amount equal to Federal receipts realized is deposited in the SPR Petroleum Account to create additional budget authority for filling the Reserve. At the end of fiscal year 1998, approximately $\$ 33$ million remained available for obligation in the Account; an amount sufficient to 
finance approximately $55 \%$ of the incremental costs of a six month emergency drawdown.

The capitalized cost for the oil in the Strategic Petroleum Reserve at the end of fiscal year 1998 was $\$ 15.09$ billion, for an average cost of approximately $\$ 27$ per barrel. The cost for the Department of Defense inventory was $\$ 125$ million for an average cost of $\$ 19.32$ per barrel. 
TABLE 7

ANNUAL APPROPRIATIONS FOR STORAGE FACILITIES OPERATIONS AND MANAGEMENT AND PETROLEUM ACQUISITION AND TRANSPORTATION

\begin{tabular}{|c|c|c|c|c|c|}
\hline Fiscal Year & Oil Account & Facilities & Management & Total & Defense SPR \\
\hline 1976 & 0 & 300.000 & 13,975 & 313,975 & \\
\hline 1977 & 440.000 & 0 & 7,824 & 447.824 & \\
\hline 1978 & 2.703 .469 & 463.933 & 14,704 & $3,182,106$ & \\
\hline 1979 New BA & 2.885 .670 & 103,290 & 18,111 & $3,007,071$ & \\
\hline Reprogramming & $(529.214)$ & $\underline{529.214}$ & & $\underline{0}$ & \\
\hline Total 1979 Appropriatiońs & 2.356 .456 & 632.504 & 18.111 & 3.007 .071 & \\
\hline 1980 Rescission & $(2.000 .000)$ & & & $(2,000,000)$ & \\
\hline $\begin{array}{l}\text { Reprogramming - No. } 1 \\
\text { Reprogramming - No. } 2 \\
\text { Total } 1980 \text {-ypropnations }\end{array}$ & $\begin{array}{r}(20.391) \\
(1.881) \\
(2.022 .272) \\
\end{array}$ & 0 & $\begin{array}{r}20.391 \\
\frac{1,881}{22.272} \\
\end{array}$ & $\begin{array}{r}0 \\
\underline{0} \\
(2,000.000)\end{array}$ & \\
\hline 1981 & 2.688 .282 & 82.834 & 19,391 & $2,790.507$ & \\
\hline Entitlements & 542.146 & 0 & 0 & 542.146 & \\
\hline $\begin{array}{l}\text { Reprogramming - Nio. } 1 \\
\text { Reprogramming - io. } 2\end{array}$ & $\begin{array}{r}(18.000) \\
(7.334)\end{array}$ & $\begin{array}{r}18.000 \\
7334\end{array}$ & 0 & $\begin{array}{l}0 \\
0\end{array}$ & \\
\hline Total 1981 Approprations & 3.205 .094 & 108.168 & 19.391 & $3,332,65 \overline{3}$ & \\
\hline 1982 & 3.684 .000 & 171.356 & 20,076 & $3,875.432$ & \\
\hline Reprogrammings & $(4.300)$ & +.300 & & $\underline{\mathbf{0}}$ & \\
\hline Total 1982 tpproprations & 3.679 .700 & 175.656 & 20.076 & $3,875.43 \overline{2}$ & \\
\hline 198.3 & 2.074 .060 & 222.528 & 19.590 & 2.316 .178 & \\
\hline 1984 & 650.000 & $1+2.357$ & 16.413 & 808.770 & \\
\hline 1985 & 2.049 .550 & +11.300 & 17.890 & 2.508 .740 & \\
\hline 1986 & 0 & 94.1115 & 13.518 & 107.533 & \\
\hline Reprogranumings & $(12.904)$ & $12 \%(1-1$ & $\underline{0}$ & $\underline{0}$ & \\
\hline Total 1986 & $112.96+1)$ & $\overline{10(0.979}$ & $13.51 \overline{8}$ & $107.53 \overline{3}$ & \\
\hline 1987 & 0 & $1+4021$ & 13.412 & 147.433 & \\
\hline 1988 & 438.744 & 151.886 & 12.276 & 602.906 & \\
\hline 1989 & 242.0001 & $1(0) .021$ & 13.400 & 415.421 & \\
\hline 1990 & .371 .916 & 174.530 & $12: 953$ & 564.399 & \\
\hline 1991 & 560.318 & $18 . .728$ & 12.846 & 766.892 & \\
\hline 1992 & $88+113$ & 171.678 & 13.384 & 273.475 & \\
\hline 1993 & $(125.625)$ & $10.1 .9+1 \mid$ & 14.227 & 50.542 & \\
\hline DOD Transfer (non add) & $12+.925$ & $7(x)$ & 0 & 125.625 & 125.625 \\
\hline 1994 & 1) & 191.0136 & 15.775 & 206.810 & \\
\hline 1995 & $1107.70+1$ & 230.938 & 16.780 & 135.954 & \\
\hline $\begin{array}{l}1996 \text { transfer from SPR } \\
\text { Petsoleum ficount }\end{array}$ & (187.(KK)1) & $171.1^{-3}$ & 16.827 & 0 & \\
\hline 1996 Wecks k (D) Sale & $(97.11+1)$ & $9-.114$ & 0 & & \\
\hline $\begin{array}{l}1996 \text { delicit reduction oul sale } \\
1996 \text { Total }\end{array}$ & $\frac{(227.000)}{(511.11+1}$ & $\frac{0}{30 \div 2 x^{2}}$ & 16.827 & $\frac{(227.000)}{(227.000)}$ & \\
\hline $\begin{array}{l}1997 \\
\text { Rexission } \\
1997 \text { Total }\end{array}$ & $\begin{array}{r}(220.0(0)) \\
0 \\
(220.00(0))\end{array}$ & $\begin{array}{l}2(13.411 \\
111.4111 \\
193 .(10)\end{array}$ & $\begin{array}{r}16.589 \\
(589) \\
16.000 \\
\end{array}$ & $\begin{array}{r}0 \\
(11.000) \\
(11.000)\end{array}$ & \\
\hline 1998 & 0 & (11)1.5()1) & 16.000 & 207.500 & \\
\hline Total Thru FY 1998 & 15.865 .981 & 4.8119 .989 & 357,644 & $21,033,614$ & 125,625 \\
\hline 1999 & 0 & $1+5.120$ & 15,000 & 160,120 & \\
\hline
\end{tabular}

Note: FI 1991 SPR Petroleum tccount of 5566.318 includes proceeds of 5122.681 from the Test Sale authorized by' the President on September 26,1990, pursuant to the EPC 1 authorities enacted September 15. 1991. in P.I. 101-383. These proceeds are recorded as addirional budget authority rather than reductions to obligations. costs. and aulays. It also includes 5315.424 .985 in Desen Storm Drawdonm proceeds and 519.755 .064 from FY 1991 NPR excess receipts. Thus the cumulative budget authoru! is "gross" and itot related durectly to the inventon. of oil on hand.

Data as of December 31. 1998 


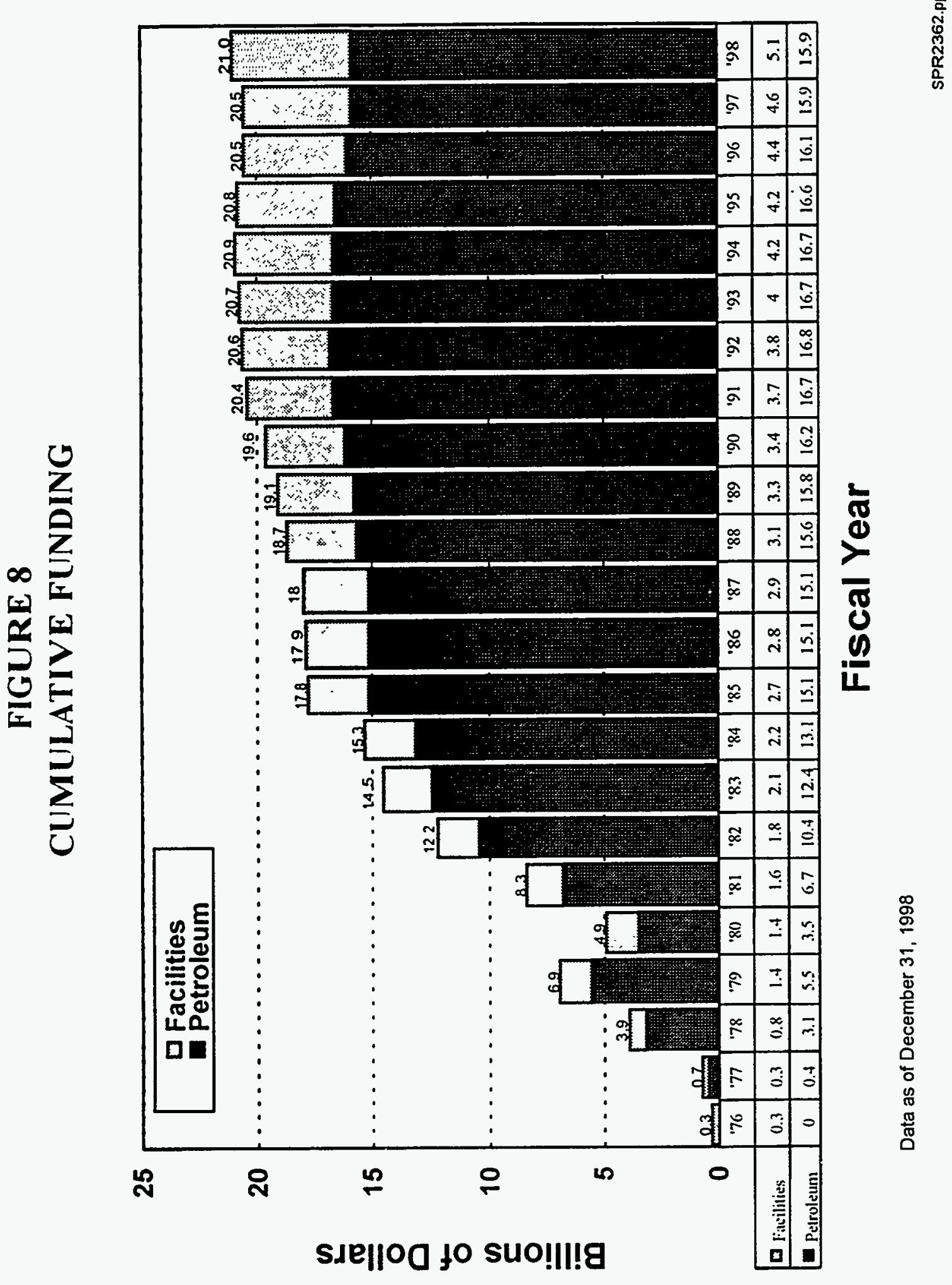




\section{COMMERCIALIZATION REVENUES}

As summarized in Table 8, the Strategic Petroleum Reserve generated $\$ 883,535$ in revenues for the U.S. Treasury from leases of distribution facilities during calendar year 1998.

TABLE 8

\section{SUMMARY OF COMMERCIALIZATION REVENUES}

\begin{tabular}{|c|c|c|c|}
\hline FACILITY OR ASSET & 1996 & 1997 & 1998 \\
\hline St. James Terminal & No Lease & $\$ 133,300$ & $\$ 481,010$ \\
\hline Bayou Choctaw Pipeline & No Lease & 0 & 0 \\
\hline Big Hill Pipeline & $\$ 472,809$ & $\$ 429,824$ & $\$ 402,525$ \\
\hline Bryan Mound Pipelines & $\$ 102,606$ & No Lease & - $\quad$ No Lease \\
\hline Total Revenue & $\$ 575,415$ & $\$ 563,124$ & $\$ 883,535$ \\
\hline
\end{tabular}

Notes:

a. Bryan Mound crude pipelines were first leased to Seaway. Pipeline Company in May 1996

b. Big Hill crude pipeline was leased to Texaco Pipe Line Inc. on May 15. 1996

c. St. James Terminal was leased to Shell Pıpelıne Company on January 31, 1997

d. Bayou Choctaw crude pipeline was leased to Shell Pipcline Co. on May 1. 1997

e. Big Hill crude pipeline was released to Tevaco Pipe Line Inc. on October 15. 1997

Data as of December 31. 1998 
Strategic Petroleum Reserve Annual Report 1998

\section{OTHER ACTIVITIES}

\section{REGIONAL PETROLEUM RESERVE REPORT}

In June 1998, the Department of Energy submitted a "Report to Congress on the Feasibility of Establishing a Heating Oil Component to the Strategic Petroleum Reserve." The report examined the vulnerability of the Northeast to disnuptions and price spikes in the price of heating oil. It specifically evaluated the feasibility, costs and benefits of creating a distillate (heating oil) reserve as part of the Strategic Petroleum Reserve. The study and report were precipitated by low inventories of heating oil, and associated high prices, in the Fall of 1996.

The report contained insights and detailed analysis regarding the causes of high heating oil prices and the pros and cons of a distillate reserve, but did not make any recommendations. The "U.S Statement of Policy on the Strategic Petroleum Reserve". issued on May 13, 1998, reaffirmed the Department's position that a Government-owned and controlled crude oil reserve in the Gulf Coast region is the most cost-effective way to ensure continued oil product supplies in a severe oil supply interruption and that product reserves are not required to ensure a prompt and effective response

\section{ORGANIZATIONAL IMPROVEMENT ACTIVITIES}

The Strategic Petroleum Reserve had another excellent year in continuous quality improvement The Reserve and its management and operating contractor, DynMcDermott Petroleum Operations Company, won prestigious quality awards during 1998, expanded its industry outreach efforts through a Customer Outreach Day at the Bryan
Mound site, and increased attendance and exhibits at industry meetings.

\section{QUALITY ASSURANCE}

The Quality Assurance group completed a comprehensive appraisal of the storage sites and the Project Management Office, as part of its On-Site Review Program. Teams visited each site for a one week period, beginning in October 1997 and ending in September 1998. The teams also reviewed contractor compliance with the Department's directives and orders, and adherence to required programs and procedures.

The Quality Assurance group also increased the number of independent audits. Audit assessments of Construction Management, Unclassified Computer Security and Management of New/Revised Requirements. were planned and completed during the year.

\section{FIFTH ANNUAL QUALITY EXPO}

The Strategic Petroleum Reserve sponsored its fifth annual Quality Expo on November 17 and 18, 1998, and more than 400 people attended. The theme of this year's Quality Expo was Benchmarking. The Expo presented 39 exhibits of quality improvement projects from the Department of Energy, DynMcDermott Petroleum Operations Company, and their contractors.

Individual quality improvement team competitions were held and awards presented to the winners. "Vision Awards" were given to the best organizations which won this year's competition. The Malcolm Baldrige National Quality Award Criteria were used as the basis for awards . 


\section{QUALITY COUNCILS AND IMPROVEMENTS ACTIVITIES}

The Program Office has a Quality Council, consisting of all staff personnel. During 1998, the Quality Council conducted an organizational selfassessment, in the form of a Baldrige Award application workshop, that resulted in a number of organizational improvement projects and initiatives.

The Project Management Office also has a Quality Council for monitoring the progress of quality improvement teams in specific projects. During 1998, the Council's charter was revised to give it more freedom to determine qualified improvement projects.

\section{CUSTOMER SERVICE INITLATIVES}

The Customer Service Team published a revised Customer Service Plan. It identifies employees' customer service responsibilities, and describes how to systematically improve customer service and work quality

The Customer Service Team has provided for increased participation in industry conferences. and sponsored exhibits at several major industry meetings. These included the National Petroleum Refiners Association Annual Meeting in San Francisco, California, Petro-Safe Conference in Houston. Texas, and the National Association of Foreign Trade Zones Conference in Monterey. California.

In October 1998, a Customer Outreach Day was held at the Bryan Mound storage facility The event was attended by 137 visitors, including representatives of domestic and foreign oil companies, terminal companies, contractors, government agencies, and elected officials. The event included a site tour, demonstrations, and exhibits.

\section{QUALITY AWARD EXAMINERS}

The Strategic Petroleum Reserve sponsored several of its employees to become quality award examiners. For the first time, two employees served as examiners for the Presidential Quality Award. Also, six employees served as Energy Quality Award examiners, and three served as quality award examiners for the State of Louisiana.

All examiners were trained in the Maicolm Baldrige National Quality Award Criteria evaluation process and conducted site evaluations at Federal, Department of Energy, and Louisiana organizations. 


\section{ENVIRONMENT, SAFETY, AND HEALTH}

The Strategic Petroleum Reserve successfully implemented the Department of Energy's Integrated Safety Management System. This system addresses how the Reserve manages and performs work. The objectives of the system are to weave environmental, safety, and health considerations into management and work practices at all levels in order to accomplish the Reserve mission while protecting the public, workers, and the environment.

In October 1998, the Reserve co-hosted a Department of Energy conference on Integrated Safety Management in New Orleans. By year's end, the Reserve deemed its Integrated Safety Management System fully implemented and is preparing to verify it in 1999 .

Pollution prevention, waste minimization. and recycling are an integral part of the Reserve's routine activities, such as inventory management. maintenance, procurement, warehousing. property management, finance. budgeting. and engineering. During 1998, the Reserve did not attain its hazardous waste reduction goals for the year because of the quantity of solvent-based paints used in maintenance and construction However, paper recycling continued to be successful, surpassing expectations, and pollution prevention continued to contribute substantial savings to the Reserve's operating costs

Two major environmental reviews of projects were conducted pursuant to the National Environmental Policy Act (NEPA) Compliance Program. In September, the Reserve prepared an Environmental Assessment of Bayou Choctau Pipeline Extension to Placid Refinery (DOE/EA-1251) and issued a Finding of No Significant Impact. This action supported the decision to change the Bayou Choctaw Pipeline lease to enable the lessee, Equilon, to construct a privately owned, 16-mile common carrier pipeline from Bayou Choctaw to Placid Refinery near Port Allen, Louisiana. The Reserve facilitated its NEPA process by coordinating it with the U.S. Army Corps of Engineers Section 404 permit process for construction in waterways and wetlands. The principal impact expected was the clearing of up to 86 acres of bottomland hardwoods (forested swamp). With careful planning and execution, Equilon was able to limit the cutting of trees so that only 37 acres will require compensatory wetlands mitigation.

In addition, Sandia National Laboratories was tasked to conduct a second Risk Assessment of Weeks Island decommissioning to address changed circumstances of oil recovery and geologic stability. Sandia's follow-up Risk Assessment, which was completed at year's end, substantiated the previous conclusions of the 1995 Environmental Assessment and Finding of No Significant Impact. No further NEPA review of Weeks Island is required at this time.

Other planned activities, such as Life Extension projects, routine operations, and facility and equipment repairs, replacements, or upgrades, also were reviewed throughout the year for environmental consequences to determine whether they required further review under NEPA.

Groundwater has been monitored for salinity and hydrocarbons at Bayou Choctaw, Big Hill, Bryan Mound, and West Hackberry for many years. In 1998, a groundwater monitoring program was added at Weeks Island to monitor for hydrocarbons. At West Hackberry, a groundwater remediation program has been in place to correct contamination from a leaking brine pond. During the preceding four years, groundwater recovery stabilized the shape and extent of the salinity plume within site boundaries. In 1998, the brine pond was replaced by aboveground tanks and removed from service. This eliminated the source of 
contamination. There continued to be no detectable hydrocarbon contamination in the groundwater at any site.

At St. James Terminal, the Reserve made progress in correcting soil contamination in a 340-square-foot area around the crude oil booster pump station. Based on investigations completed during the year, the Reserve believes the situation meets criteria for monitored natural attenuation (i.e., passive remediation that relies on natural degradation of the oil) under the State's new Risk Evaluation/Corrective Action Program. In return for monitoring the site twice yearly, the Reserve would avoid removing and disposing of more than 1300 cubic feet of soil and could save more than $\$ 70,000$

Under the first full year of the Behavioral Safety Program, employees exhibited safe behaviors 94 percent of the time as determined by observations by fellow employees. Despite this accomplishment, there was a slight increase in total recordable illnesses and injuries among contractor and subcontractor personnel. attributable mainly to the substantial increase in major maintenance and Life Extension construction activities. The Reserve also implemented an ergonomics program at all sites. which included ergonomics awareness training for all personnel

Ongoing Life Extension construction. Weeks Island decommissioning activities. and commercialization initiatives necessitated numerous actions to renew, extend, modifi: and/or update various environmental permits To date, the Reserve has been unsuccessful in obtaining an approved alternative to the current dual reporting of National Pollutant Discharge Elimination System permit requirements to both Louisiana and the Environmental Protection Agency. For the year, there was one oil spill of less than one-half pint that produced a sheen on an irrigation ditch; three brine spills, the largest of which was 30 barrels; and 11 self-reported permit non-compliances, none of which resulted in environmental damage.

During the year, there were seven environmental inspections by Federal and State agencies. In addition, the Occupational Safety and Health Administration conducted two site inspections that resulted in one minor citation (without fine) for misrecorded data on a three-year old occupational illness record. The Reserve conducted its own inspections, audits, and assessments for Safety and Health, Process Safety Management, and Federal Employee Occupational Safety and Health at all five sites, and assessed the procedures and performance of four of its own laboratories. 


\section{EMERGENCY MANAGEMENT PROGRAM}

The Strategic Petroleum Reserve continued to maintain a high level of readiness under its emergency management program to protect the environment, workforce and facilities. Significant activities during the year included:

- Training site Emergency Response Teams in oil spill and fire protection;

- Developing standardized confined space rescue training and procedures:

- Conducting emergency response exercises at each of the sites;

- Acquiring a new communications vehicle with expanded capability to support extended field emergency operations.

- Completing the high-volume fire equipment upgrade with the acquisition of four 1500 gallon-per-minute pumper fire trucks;

- Updating various emergency response plans and procedures:

- $\quad$ Supporting local community emergency planning and management.

- Acquiring a Hurricane Tracking System for expanding the Reserve's ability to reliably. collect, develop and disseminate critical weather information; and

- Enhancing the Annual Equipment Deployment Exercises required by the National Preparedness for Response Exercise Program, so as to annually validate each site's response readiness in lieu of the Reserve's prior annual single
Emergency Exercise (EMEX) that tested only one or two sites per year.

\section{SECURITY}

Borg-Warner Protective Services Corporation provides protection services through a subcontract with the Reserve's management and operating contractor, DynMcDermott Petroleum Operations Company. The current protection force includes 145 armed officers who provide protection for the four storage sites and the Project Management Office complex.

As part of the Life Extension Program, site physical security systems, such as intrusion detection equipment and alarm displays, are being upgraded.

The Reserve, through its security program, continues to actively maintain formal liaison with outside federal, state and local law enforcement agencies who would respond to emergencies at Strategic Petroleum Reserve facilities.

Periodical tactical exercises with outside law enforcement agencies, and continued intensive training, ensure that the protective force maintains its proficiency. In September 1998, 40 members of the New Orleans Office of the Federal Bureau of Investigation (FBI), participated with the protection force in a joint tactical exercise at the Reserve's complex in New Orleans. This included simulating a terrorist/hostage situation requiring the response of a Special Weapons and Tactics (SWAT) Team, Crisis Negotiation Team and Tactical Operations Center. The FBI has lead agency jurisdiction for counter-terrorism, and this is the first exercise of its kind involving the Strategic Petroleum Reserve. The deployment of a regional FBI SWAT Team was a significant accomplishment for the Reserve, requiring over two years of planning. 
Since November 1998, the Reserve has been on "enhanced vigilance" status in response to tensions in the Middle East.

\section{REAL ESTATE ACTIONS}

The U.S. Army Corps of Engineers' interagency agreement DE-AI96-78PO02816 was extended for an additional five year period from 1998 to 2003 to provide real estate assistance to the Strategic Petroleum Reserve.

The Department acquired through the U.S. Army Corps of Engineers, Galveston District, two Big Hill pipeline easements ( 0.059 and 0.215 acres) from Sun Pipeline Company. 
Strategic Petroleum Reserve Annual Report 1998

\section{APPENDIX A}

\section{Strategic Petroleum Reserve Site Information}

\section{BRYAN MOUND}

Location

Brazoria County, Texas (three miles southwest of Freeport, Texas).

Site Description

232-million-barrel storage facility consisting of 20 caverns.

24-inch diameter, 6-mile brine disposal pipeline extending 4 miles offshore in the Gulf of Mexico.

Oil, brine and raw water piping distribution system connecting caverns with central plant and water intake structure located on Brazos River. Twentyfour(24) pumps totaling approximately $\mathbf{4 7 . 0 0 0}$ horsepower.

\section{System Parameters}

- Drawdown Rate: $\quad 1,500,000 \mathrm{bbl} / \mathrm{d}$

- Raw Water Pumping Rate $1,545,000 \mathrm{bbl} / \mathrm{d}$

- Oil Fill Rate: $\quad 225.000 \mathrm{bbl} / \mathrm{d}$

- Brine Disposal Rate: $\quad 360,000$ bbl/d

Distribution Facilities

- DOE 3.9 mile, 30-inch pipeline to Seaway Freeport Marine Terminal

- DOE 4.0 mile, 30-inch pipeline to Seaway. Jones Creek Tank Farm and Pipeline

- DOE 46 mile, 40-inch pipeline to Seaway. Texas City Terminal and Docks

\section{Acquisition}

Acquired 499.47 acres fee simple. by condemnation April 1977, from Freeport Mineral Company and other owners. Dow Chemical Company was the previous operator.

\section{WEST HACKBERRY}

\section{Location}

Cameron Parish, Louisiana ( 22 miles southwest of Lake Charles, Louisiana).

Site Description

222-million-barrel storage facility consisting of 22 caverns.

Oil, brine, and raw water piping distribution system connecting caverns with central plant, water intake structure located on Intracoastal waterway and 10 brine disposal wells. Twenty(20) pumps totaling over 40,000 horsepower.

System Parameters

- Drawdown rate: $\quad 1,300,000 \mathrm{bbl} / \mathrm{d}$

- Raw Water Pumping Rate: $1,339,000 \mathrm{bbl} / \mathrm{d}$

- Oil Fill Rate: $\quad 225,000 \mathrm{bbl} / \mathrm{d}$

- Brine Disposal Rate: $\quad 240,000$ bbl/d

Distribution Facilities

- $\quad$ DOE 42.8 mile, 42-inch pipeline to Sunoco Nederland Terminal

- DOE 13.6 mile, 36-inch pipeline to Equilon common carrier pipeline system at Lake Charles

Acquisition

Acquired 405.36 acres fee simple, by condemnation April 1977, from numerous private landowners. Olin Corporation was the previous site operator. Acquired 160.0 additional acres fee simple by condemnation in two actions, July 1979 and March 1980. 
Strategic Petroleum Reserve Anmual Report 1998

\section{BIG HILL}

Location

Jefferson County, Texas (20 miles southwest of Beaumont, Texas).

Site Description

170-million-barrel storage facility consisting of fourteen caverns.

Oil, brine, and raw water systems connecting caverns with central plant, water intake structure located on the Intracoastal Waterway, and a 48inch diameter, 14-mile brine disposal pipeline extending 5 miles offshore in the Gulf of Mexico. Seventeen(17) pumps totaling 37,000 horsepower.

\section{System Parameters}

- Drawdown Rate: $\quad 930,000 \mathrm{bbl} / \mathrm{d}$
(Will increase to $1,100,000 \mathrm{bbl} / \mathrm{d}$ in 2000 )
Raw Water Pumping Rate: $1,400,000 \mathrm{bbl} / \mathrm{d}$
- $\quad 225,000 \mathrm{bbl} / \mathrm{d}$
Oil Fill Rate:
Brine Disposal Rate: $\quad 280.000 \mathrm{bbl} / \mathrm{d}$

Distribution Facilities

- DOE 24.5 mile, 36-inch pipeline to Sunoco Nederland Terminal

- Unocal 2 mile. 36-inch pipeline to L ñocal Docks

- Equilon 20-inch pipeline system to East Houston

\section{Acquisition}

Acquired 271 acres fee simple, by condemnation November 1982 and July 1983. from three landowners, i e., 238.48 acres from Amoco. 2706 acres from the Pipkin estate, and 5.46 acres from the Patrick Henry Phelan estate.

\section{BAYOU CHOCTAW}

\section{Location}

Iberville Parish, Louisiana (12 miles southwest of Baton Rouge, Louisiana).

\section{Site Description}

76-million-barrel storage facility consisting of six caverns.

Oil, brine, and raw water piping distribution system connecting caverns with central plant, a water intake structure, 12 brine disposal wells, and a pipeline for disposing of brine to Union Texas Petroleum, Inc. Seventeen(17) pumps totaling over 21,000 horsepower.

\section{System Parameters}

- Drawdown Rate: $\quad 480,000 \mathrm{bbl} / \mathrm{d}$ (Will increase to $515,000 \mathrm{bbl} / \mathrm{d}$ in 1999)

- Raw Water Pumping Rate: 514,000 bbl/d

- Oil Fill Rate: $75,000 \mathrm{bbl} / \mathrm{d}$

- Brine Disposal Rate: $\quad 75,000 \mathrm{bbl} / \mathrm{d}$

\section{Distribution Facilities}

- DOE 37.2 mile, 36-inch pipeline to Equilon's Sugarland Terminal and Capline Pipeline.

\section{Acquisition}

Acquired 355.95 acres fee simple, by condemnation April 1977, from numerous private owners. Union Texas Petroleum (a subsidiary of Allied Corporation) was the previous operator.

In 1985 the Department of Energy acquired an additional existing cavern through a cavern exchange agreement with Union Texas Petroleum. The transaction involved a 3.5 acre exchange with no net change in Government-owned acreage. 